Review

\title{
Non-Canonical Host Intracellular Niche Links to New Antimicrobial Resistance Mechanism
}

\author{
Michaela Kember ${ }^{\dagger}$, Shannen Grandy ${ }^{\dagger}$, Renee Raudonis *DiD and Zhenyu Cheng *D
}

check for updates

Citation: Kember, M.; Grandy, S.; Raudonis, R.; Cheng, Z.

Non-Canonical Host Intracellular

Niche Links to New Antimicrobial

Resistance Mechanism. Pathogens 2022, 11, 220. https://doi.org/ $10.3390 /$ pathogens 11020220

Academic Editor: Claudio Farina

Received: 2 December 2021

Accepted: 5 February 2022

Published: 8 February 2022

Publisher's Note: MDPI stays neutral with regard to jurisdictional claims in published maps and institutional affiliations.

Copyright: (C) 2022 by the authors. Licensee MDPI, Basel, Switzerland. This article is an open access article distributed under the terms and conditions of the Creative Commons Attribution (CC BY) license (https:// creativecommons.org/licenses/by/ $4.0 /)$.
Department of Microbiology and Immunology, Faculty of Medicine, Dalhousie University, Halifax, NS B3H 4R2, Canada; michaela.kember@dal.ca (M.K.); sgrandy@dal.ca (S.G.)

* Correspondence: r.raudonis@dal.ca (R.R.); zhenyu.cheng@dal.ca (Z.C.)

+ These authors contributed equally to this work.

\begin{abstract}
Globally, infectious diseases are one of the leading causes of death among people of all ages. The development of antimicrobials to treat infectious diseases has been one of the most significant advances in medical history. Alarmingly, antimicrobial resistance is a widespread phenomenon that will, without intervention, make currently treatable infections once again deadly. In an era of widespread antimicrobial resistance, there is a constant and pressing need to develop new antibacterial drugs. Unraveling the underlying resistance mechanisms is critical to fight this crisis. In this review, we summarize some emerging evidence of the non-canonical intracellular life cycle of two priority antimicrobial-resistant bacterial pathogens: Pseudomonas aeruginosa and Staphylococcus aureus. The bacterial factors that modulate this unique intracellular niche and its implications in contributing to resistance are discussed. We then briefly discuss some recent research that focused on the promises of boosting host immunity as a combination therapy with antimicrobials to eradicate these two particular pathogens. Finally, we summarize the importance of various strategies, including surveillance and vaccines, in mitigating the impacts of antimicrobial resistance in general.
\end{abstract}

Keywords: non-canonical intracellular pathogen; antibiotic resistance; Pseudomonas aeruginosa; Staphylococcus aureus

\section{Introduction}

Infectious diseases remain one of the most pressing challenges faced by humanity today. The recently emerged severe acute respiratory syndrome coronavirus-2 (SARSCoV-2), the causative agent of the ongoing pneumonia-like pandemic of coronavirus disease 2019 (COVID-19), has infected over 355 million and killed over 5.6 million people worldwide as of January 2022 [1]. This toll on the healthcare system, along with the resultant social and economic turbulences, highlights the importance of pandemic preparedness. Although public health experts believe that respiratory-borne RNA viruses, such as the corona and influenza viruses, are most likely to cause naturally occurring global infectious catastrophes [2], the rapid emergence of bacterial and fungal infections associated with antimicrobial resistance (AMR) also sound the alarm for widespread deadly infections caused by these microorganisms and remain an ongoing priority for risk preparedness [3-8].

The World Health Organization (WHO) declared AMR as one of the top 10 global public health threats facing humanity in 2019 [9]. Although antimicrobials broadly include antibiotics, antivirals, antifungals, and antiparasitics, the focus of our current review is on antibiotics. The AMR infections pose serious threats to public health, including high mortality rates, unaffordability by the necessity of more intensive care and use of costly alternative drugs, and more risks during surgeries and cancer therapies [10-16]. The most prominent projection of the severity of the AMR problem was made by Lord Jim $\mathrm{O}^{\prime}$ Neill and their team in the AMR Review entitled "Antimicrobial Resistance: Tackling $a$ crisis for the health and wealth of nations", which predicted that by 2050 there could be about ten million deaths per year due to AMR [17]. This review has been the cornerstone of 
global actions on AMR control and widely accepted. A recent study published online in January 2022, which presented the most comprehensive investigation of AMR burden to date, estimated there were about 5 million deaths associated with bacterial AMR in 2019 [18]. The development of antibiotics as antibacterial therapeutics revolutionized modern medicine. Paul Ehrlich's screening and identification of drugs against syphilis [19], together with the discovery of penicillin by Alexander Fleming [20] and its mass production enabled by Howard Florey and Ernest Chain's purification protocol [21], marked landmark discoveries in modern antibiotics [22]. The broad use of penicillin was followed by the golden era of antibiotics discovery in the period between the 1950s and 1970s. However, no new classes of antibiotics have been discovered in decades. The lack of new treatment combined with the rapid development and spreading of resistance sound the alarm for the AMR crisis. It is crucial to better understand the underlying AMR mechanisms to tackle this problem. Major mechanisms of resistance include: (1) limiting uptake with restricted membrane permeability or by efflux pump; (2) inactivation of drugs; or (3) modification of drug targets [23].

In addition, a group of bacteria known as intracellular bacteria can gain entry to host cells, followed by bacterial manipulations of host cell biology to create a unique niche within the host cell environment as part of their infection cycles [24]. Classical examples of intracellular bacteria include members from genus of Mycobacterium, Salmonella, Chlamydia, Listeria, Shigella, Legionella, Brucella, and Rickettsia. Intracellular bacteria possess unique resistance strategies [25]. To treat intracellular bacteria, different classes of antibiotics can pass host cell plasma membrane via various routes, as $\beta$ lactams, macrolides, and quinolones pass by diffusion [26], whereas aminoglycosides by receptor megalin-mediated endocytosis [27] (Table 1). However, it is still challenging for antibiotics to reach and stay active inside host cell and sometimes subcellular membrane-concealed organelles where intracellular bacteria hide. Moreover, to survive stresses within the host environment, intracellular bacteria often trigger a physiological switch to a non-replicating or slowly replicating state [28], which also reduces their susceptibility to antibiotics [29]. Mycobacterium tuberculosis exemplifies this sophisticated strategy [30]: this bacterium initiates infections by infiltrating the epithelial lining and replicating in alveolar macrophages with bacteria-obstructed phagosome-lysosome fusion. Mycobacteria eventually establish latent infections in granulomas, clusters of infected macrophages, neutrophils, epithelioid cells, and foam cells that are encircled by the recruited T and B lymphocytes [31,32]. The non-replicating latent infection state is resistant to conventional treatment [33].

Staphylococcus aureus and Pseudomonas aeruginosa, two priority antimicrobial-resistant bacterial pathogens, are typically considered not to be intracellular. However, emerging evidence suggests that these two species can also be associated with life cycles inside host cells, and while there is an ever-growing mountain of evidence for $S$. aureus as an intracellular pathogen, there is only a handful of evidence of P. aeruginosa's lifestyle as an intracellular pathogen currently available. In this review, we summarize the specific virulence mechanisms underlying this unique intracellular niche and discuss their implications in contributing to resistance in these two priority pathogens. At last, we focus on the discussions about the potentials of combating these two specific pathogens by harnessing host immunity as a combination therapy with antimicrobials and provide a general summary of the key roles of surveillance and vaccines in limiting AMR. 
Table 1. Common classes of antibiotics in use, their mode of action, and host cell permeability.

\begin{tabular}{|c|c|c|}
\hline Antibiotic Class & Mode of Action & Host Cell Permeable [25-27] \\
\hline Aminoglycosides & Inhibit protein synthesis & $\begin{array}{l}\text { Yes, some antibiotics in this class enter host cells } \\
\text { via endocytosis }\end{array}$ \\
\hline Ansamycins & Inhibit RNA synthesis & Yes, rifamycin enters via passive uptake (diffusion) \\
\hline$\beta$-Lactams & Inhibit cell wall synthesis & $\begin{array}{l}\text { Yes, small molecules via diffusion, larger } \\
\text { molecules possibly via endocytosis }\end{array}$ \\
\hline Chloramphenicol & Inhibits protein synthesis & $\begin{array}{l}\text { No, requires modification for enhanced entry } \\
\text { into host cells }\end{array}$ \\
\hline Glycopeptides & Inhibit cell wall synthesis & $\begin{array}{l}\text { No, requires modification for enhanced entry } \\
\text { into host cells }\end{array}$ \\
\hline Lipopeptides & Disrupt cell membrane functions & No/Unknown \\
\hline Macrolides & Inhibit protein synthesis & Yes, diffusion and partly active uptake \\
\hline Oxazolidinones & Inhibit protein synthesis & Yes, passive uptake \\
\hline Quinolones & Interfere with bacterial DNA replication & $\begin{array}{l}\text { Yes, active and passive cellular uptake, depending } \\
\text { on the quinolone }\end{array}$ \\
\hline Streptogramins & Inhibit protein synthesis & No/Unknown \\
\hline Sulfonamides & Inhibit folic acid synthesis & Yes, active uptake \\
\hline Tetracyclines & Inhibit protein synthesis & Yes, active uptake \\
\hline
\end{tabular}

\section{P. aeruginosa as an Intracellular Pathogen}

\subsection{Overview}

Pseudomonas aeruginosa is a Gram-negative ubiquitous bacterium and an opportunistic pathogen that is responsible for a wide variety of infections [34]. Typical infections caused by P. aeruginosa consist of bacteremia in burn patients, hospital acquired pneumonia in ventilated patients, and urinary tract infections in patients with catheters [34]. P. aeruginosa infection is of particular concern to those who are immunocompromised, especially cystic fibrosis (CF) patients [35].

Multiple virulence factors contribute to the ability of P. aeruginosa to establish both acute and chronic infections. These virulence factors include but are not limited to phospholipase C, proteases, exotoxins, cytotoxins, flagella, pili, and secretion systems [36]. Protein secretion systems are important for delivering virulence factors such as exotoxins and cytotoxins to the extracellular environment and directly into other cells. P. aeruginosa utilizes five secretion systems: type 1, type 2, type 3, type 5, and type 6 [37]. The type 3 secretion system (T3SS) and type 6 secretion system (T6SS) allow P. aeruginosa to deliver toxins directly into mammalian and bacterial target cells [37]. Both the T3SS and T6SS are implicated in P. aeruginosa's intracellular life cycle as will be discussed below.

$P$. aeruginosa infections are difficult to treat and are becoming an increasing threat due to multiple antibiotic resistance mechanisms including intrinsic, acquired, and adaptive mechanisms. Intrinsic antimicrobial resistance features of $P$. aeruginosa include efflux pumps, low outer membrane permeability, and the synthesis of enzymes that are antibiotic inhibiting/inactivating [38]. Acquired resistance can occur by the acquisition of genes from other species or organisms through the uptake of plasmids, bacteriophages, or transposons [39]. The ability of P. aeruginosa to produce biofilms plays a major role in infection and contributes to adaptive resistance; this form of resistance is particularly difficult to treat in infections [40].

Another aspect of $P$. aeruginosa that makes it difficult to treat is its striking strainto-strain diversity. While the average genome size of $P$. aeruginosa ranges from 5.5 to $7 \mathrm{Mbp}$, the core genome consists of only 321 genes [41,42]. The high plasticity of the P. aeruginosa genome contributes to its ability to evade antibiotics and cause a wide range of infections [43]. While clinical isolates tend to have smaller genomes compared with 
environmental and industrial strains, the antibiotic susceptibility and virulence factors between isolates can vary drastically $[43,44]$. Therefore, it is difficult to develop a single targeted treatment for all $P$. aeruginosa infections.

While $P$. aeruginosa is traditionally known to be an extracellular pathogen, there is increasing evidence that shows it can invade and survive within host cells. The ability to switch between being an extracellular and intracellular pathogen has been reported for other bacterial species and is a commonly used tactic to evade host defenses [45]. For example, uropathogenic E. coli can become an intracellular pathogen, allowing it to establish an intracellular reservoir in bladder epithelial cells, which makes eradication challenging [45]. Since $P$. aeruginosa infections are already difficult to eradicate, the ability of $P$. aeruginosa to establish intracellular reservoirs poses additional complications for treatment. Therefore, understanding how P. aeruginosa invades, survives, and persists within host cells is crucial for eradication of infections.

\subsection{Intracellular Lifestyle of P. aeruginosa}

Within host cells, P. aeruginosa has been shown to aggregate in blebs or biofilm-like structures, alter host cytoskeletal elements, and be tolerant to antibiotics [46-49]. P. aeruginosa has also been found intracellularly in multiple epithelial cell types including lung, corneal, and bladder, as well as phagocytic cells such as macrophages [46,49-51]. The strategies employed by P. aeruginosa to function as an intracellular pathogen are not well understood; however, the following sections will highlight some of the preliminary discoveries around potential intracellular invasion and survival mechanisms.

\subsubsection{P. aeruginosa Invasion of Host Cells}

P. aeruginosa possesses three type 6 secretion systems (T6SS) located on three different loci-they are named H1, H2, and H3, respectively [37]. The T6SS allows P. aeruginosa to deliver toxins to both prokaryotic and eukaryotic target cells [37]. The H2-T6SS plays a role in the internalization of $P$. aeruginosa into eukaryotic cells; H2-T6SS mutants showed a 75\% decrease in P. aeruginosa internalization into lung epithelial cells [49]. The T6SS structure resembles the contractile tail of a bacteriophage, allowing it to puncture the target cells to deliver toxins [45]. The H2-T6SS puncturing device contains valine glycine repeat $\mathrm{G}(\mathrm{VgrG})$ proteins; a subclass of these proteins called evolved VgrGs, are effectors of the T6SS, and have intracellular functions that involve interacting with the host cells actin cytoskeleton [45]. P. aeruginosa prefers to enter injured and damaged cells from the basolateral surface and can subvert the cytoskeleton remodeling pathways to invade cells from the apical surface [52]. When P. aeruginosa binds to polarized epithelial cells, phosphatidylinositol 3-kinase (PI3K) is activated, resulting in the activation of protein kinase B/Akt (Akt) and the synthesis of phosphatidylinositol 1,4,5-triphosphate (PIP3) [52,53]. Sana and colleagues found that $P$. aeruginosa's ability to activate PI3K signaling and subsequently subvert cytoskeleton remodeling pathways was dependent on the H2-T6SS [49] (Figure 1). An H2-T6SS mutant (PAO1 $\Delta c l p V 2$ ) cocultured with lung epithelial cells resulted in decreased P. aeruginosa invasion and phosphorylation of Akt [49].

Activation of PI3K signaling molecules and their subsequent pathways is required for the internalization of $P$. aeruginosa into epithelial cells because it results in the remodeling of the apical surface into the basolateral surface and protrusions from the cell that consist of PIP3 and actin [52,53]. Later, Sana and colleagues reported that the H2-T6SS effector VgrG2b interacts with the $\gamma$-tubulin ring complex ( $\gamma$-TuRC) as well as the alpha and beta tubulin subunits of microtubules in target cells [45] (Figure 1). VgrG2b is both part of the H2-T6SS structure and a secreted effector, allowing it to enter the host/target cells before the internalization of P. aeruginosa [54]. The role of the $\gamma$-TuRC is microtubule nucleation, allowing $\gamma$-TuRC to have control over when and where microtubule growth occurs [55]. Since Sana and colleagues found that both microtubules and actin are required for the internalization of P. aeruginosa, it is likely that it is the interaction between $\operatorname{VgrG} 2 \mathrm{~b}$ and the $\gamma$-TuRC that allows $P$. aeruginosa to subvert the cytoskeleton remodeling pathways allowing 
for internalization [49]. However, the relationship between VgrG2b, PI3K, and $\gamma$-TuRC needs to be further investigated.

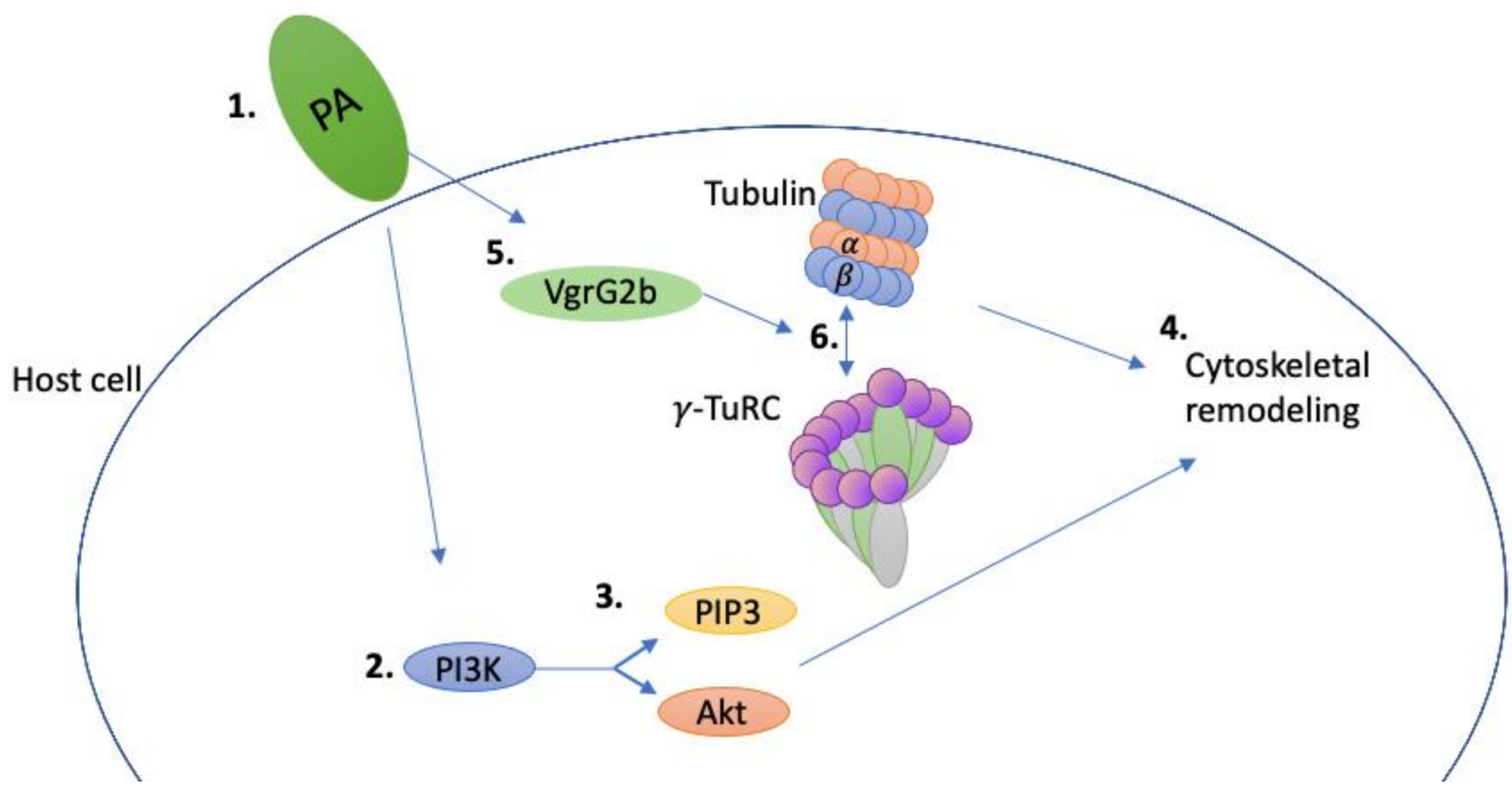

Figure 1. Depiction of $P$. aeruginosa's ability to subvert the host cell cytoskeleton. When $P$. aeruginosa (PA) binds to epithelial cells (1), it results in the activation of PI3K (2) in an H2-T6SS-dependent manner [48]. PI3K subsequently activates Akt and PIP3 via phosphorylation (3), leading to cytoskeleton remodeling (4) [49,52]. Evidence has also shown that the H2-T6SS effector VgrG2b is injected into the host cell prior to P. aeruginosa invasion (5) [54]. VgrG2b is then able to interact with $\alpha / \beta$-tubulin as well as the $\gamma$-TuRC (6) [45]. This interaction is likely to lead to cytoskeletal remodeling; however, connections between the PI3K and VgrG2b remain to be elucidated.

\subsubsection{P. aeruginosa Intracellular Survival Strategies}

The T3SS has been implicated in the intracellular survival of P. aeruginosa in phagocytic and non-phagocytic cells. Like the T6SS, the T3SS can deliver its effector proteins across membranes into target cells [37]. Four T3SS effector proteins have been found in P. aeruginosa, although no strains encode all four [56]. ExoY and ExoT are encoded by most strains and respectively encode a nucleotidyl cyclase and an enzyme that has both Rho-GTPase activating protein and ADP-ribosyltransferase domains [57,58]. ExoS is the same type of bifunctional enzyme as ExoT, and its expression is typically mutually exclusive with ExoU, a phospholipase [59]. ExoS and ExoT also play an antiphagocytic role that has been shown to prevent uptake into some cell types such as HeLa [60]. The strainto-strain variability in P. aeruginosa's expression of T3SS effectors results in some strains being cytotoxic through the expression of ExoU rather than ExoS [61]. The cytotoxicity of ExoU-expressing strains prevents them from being invasive, while strains that lack ExoU and express ExoS can be invasive; Table 2 provides examples of ExoU and ExoS expressing strains of P. aeruginosa [62].

When mutations are made in the needle of P. aeruginosa PAO1 T3SS, increased invasion of epithelial cells is observed; however, intracellular survival decreases [47], suggesting that the T3SS plays a role in the intracellular survival of P. aeruginosa rather than internalization. Further supporting the role of T3SS in intracellular survival, expression of T3SS increases between 4 and $7 \mathrm{~h}$ post infection in intracellular PAO1, suggesting an increasing demand for T3SS [60]. Angus and colleagues observed that wildtype PAO1 formed membrane blebs within corneal epithelial cells that allowed the bacteria to replicate, whereas various T3SS mutants were unable to achieve this [47]. Despite the antiphagocytic properties of 
ExoS, it is shown to be required for the development of these intracellular bleb niches that P. aeruginosa develops $[50,60]$. ExoS has also been shown to suppress vacuolar acidification, a host mechanism for killing $P$. aeruginosa, thereby contributing to intracellular replication of P. aeruginosa [63]. Together these data provide insightful details into the strategies employed by $P$. aeruginosa to survive in the intracellular environment of non-phagocytic cells.

Table 2. List of P. aeruginosa strains and their expression of ExoS or ExoU.

\begin{tabular}{|c|c|c|}
\hline Strain & ExoS & ExoU \\
\hline PAO1 & + & - \\
\hline CF18 & + & - \\
\hline CF27 & + & - \\
\hline PAK & + & - \\
\hline JJ692 & - & + \\
\hline E2 & + & - \\
\hline MSH10 & + & - \\
\hline X13273 & - & + \\
\hline
\end{tabular}

The T3SS effector ExoS is also important for survival of P. aeruginosa within macrophages, as it facilitates escape from phagosomes and macrophage lysis [51]. Cyclic di-GMP is a repressor of T3SS genes, whose expression levels are negatively correlated [51]. Recently, $m g t C$ and oprF were both identified as promoting intracellular survival within macrophages [51]. When $m g t C$ or oprF is knocked out in P. aeruginosa strain PAO1, higher levels of cyclic di-GMP were detected [51]. As well, $m g t C$ and oprF mutants were unable to survive intracellularly or induce macrophage lysis [51,64]. Garai and colleagues made T3SS mutant strains and observed that ExoS mutants displayed the same lack of ability to induce macrophage lysis as the $m g t C$ and $o p r F$ mutants, indicating that the T3SS effector also plays a role in inducing cell lysis in macrophages and might be under the control of MgtC and OprF [51].

Thus, ExoS of the T3SS promotes survival of $P$. aeruginosa within epithelial cells, allowing the bacteria to evade the host immune response and establish an intracellular niche. In addition to niche establishment, ExoS also contributes to P. aeruginosa's ability to destroy macrophages by allowing it to escape vacuoles and ultimately induce lysis. Therefore, the ability of $P$. aeruginosa to become an intracellular pathogen not only allows it to evade the immune response and antimicrobial therapy, but it also depletes phagocytic cells through ExoS-induced cell lysis.

Factors other than protein secretion systems have also been found to play an important role in $P$. aeruginosa invasion and survival in epithelial cells. AlgR is a transcriptional response regulator that controls more than 200 genes in $P$. aeruginosa and is required for invasion and intracellular survival of PAO1 in bladder epithelial cells [46]. Phosphorylated $\mathrm{AlgR}$ is required for invasion into bladder epithelial cells, while unphosphorylated AlgR is required for intracellular survival of $P$. aeruginosa [46]. Interestingly, lower levels of NF-kB activation were observed in epithelial cells invaded by AlgR mutants [46]. The multi-subunit IkB kinase (IKK) complex is an upstream kinase in the NF-kB signaling pathway that ultimately is responsible for activating NF-kB signaling, and PI3K has also been shown to be able to activate NF-kB $[46,65]$. When IKK or PI3K are inhibited and cells are infected with $P$. aeruginosa, intracellular survival of $P$. aeruginosa is decreased [46]. However, exogenous activation of the NF-kB pathways through TNF $\alpha$ did not increase the intracellular survival of $P$. aeruginosa [46]. These experiments indicate that while NF-kB signaling is required for maximal survival of $P$. aeruginosa in the intracellular environment of epithelial cells, NF-kB signaling alone is not sufficient to promote survival [46]. NF-kB is required for the clearance of extracellular pathogens including P. aeruginosa [46]; thus, the 
relationship between NF-kB signaling and intracellular survival of $P$. aeruginosa remains to be elucidated.

\subsection{Development of Intracellular P. aeruginosa Antibiotic Persister Cells}

As mentioned above, biofilm formation plays a critical role in P. aeruginosa's ability to cause acute and chronic infections in the extracellular environment. P. aeruginosa can cause membrane blebbing in host cells and establish an intracellular niche that allows for bacterial replication [50]. It has also been observed that P. aeruginosa is able to form pods with biofilm-like structures in bladder epithelial cells [48]. These bacterial cells were able to persist in the biofilm-like pods for over $72 \mathrm{~h}$, demonstrating that $P$. aeruginosa can persist for prolonged periods of time in the intracellular environment [48]. Heterogeneity is a classic characteristic of biofilms [66]. Heterogenous gene expression was observed in $P$. aeruginosa cells within the intracellular pods, which is in line with what is typically observed in biofilms [48]. While this is not definitive evidence of biofilm formation, it provides supporting evidence that the pods were intracellular biofilms. Biofilm formation in $P$. aeruginosa is also associated with the development of persister cells. The persister phenotype is enhanced when cells are exposed to stress (e.g., antibiotic treatment or nutrient deprivation), but when the stress dissipates, the wildtype phenotype is restored [67]. Importantly, persisters vary phenotypically from the wildtype but are not the result of a permanent genetic mutation [67]. The ability to revert to the wildtype as well as multidrug tolerance are two hallmarks of persister cells [64]. Within biofilms, some cells experience nutrient limitation, which can induce the persister phenotype, resulting in tolerance to multiple antibiotics [68].

A transient antibiotic tolerant phenotype has been observed in intracellular P. aeruginosa $[46,48]$. Intracellular P. aeruginosa cells treated with concentrations of ciprofloxacin 10 to 35 times the minimum inhibitory concentration resulted in a biphasic kill curve, where higher concentrations of the antibiotic resulted in increased numbers of tolerant cells [46]. This biphasic kill curve is typical of bacterial persister experiments, suggesting that $P$. aeruginosa is developing persister cells in the intracellular environment [68]. As well, when the bacteria were isolated from the intracellular environment, the wildtype susceptibility to ciprofloxacin was restored, demonstrating the ability of the tolerant cells to revert to the wildtype [46]. Garcia-Medina and colleagues observed the same reversible antibiotic tolerant phenotype in cells isolated from the intracellular biofilm pods they reported [48], further supporting the idea that $P$. aeruginosa is developing persister cells in the intracellular environment. The idea that an intracellular pathogen could develop persister cells within the host is not unheard of: Salmonella typhimurium cells within macrophage vacuoles adopted a non-replicative state typical of persister cells, allowing it to achieve long term survival against host damage and antibiotics $[69,70]$.

\subsection{Summary}

There are multiple factors that allow for intracellular invasion and promote survival of $P$. aeruginosa in the intracellular environment. However, information around specific mechanisms, such as how NF-kB signaling provides protection or how ExoS induces membrane blebbing, is still unknown. Even more questions arise around mechanisms underlying the development of intracellular biofilms and persister cells. What is clear is that $P$. aeruginosa possesses the ability to not only invade host cells but to persist within epithelial cells for extended periods of time, allowing for a potential reservoir of bacteria, contributing to the already difficult task of eradicating P. aeruginosa infection.

\section{S. aureus as an Intracellular Pathogen}

\subsection{Overview}

Staphylococcus aureus is a Gram-positive commensal bacterial species that is wellrecognized as a major human pathogen [71]. Roughly $30 \%$ of humans are colonized with S. aureus, with the human nose acting as the predominant reservoir [72]. S. aureus is 
responsible for a wide spectrum of infections ranging from various soft tissue infections to invasive systemic infections [73]. As of 2021, it remains the dominant Gram-positive bacteria responsible for aggressive nosocomial infections [74]. Despite its notorious profile as an aggressive extracellular organism, S. aureus is additionally recognized as a facultative intracellular pathogen: it is capable of entering host cells, replicating, and persisting in the host cells as part of its survival strategy [75-77]. The potential benefits of this practice are twofold in nature: intracellular persistence helps $S$. aureus avoid detection by professional phagocytes, evading host bactericidal defenses and detection by host pattern recognition receptors; it additionally offers concurrent protection from antibiotic therapies. Such factors impact patient recovery from staphylococcal infection while concomitantly increasing the severity of illness [78]. Intracellular localization of S. aureus has been suggested to contribute to the often prolonged, chronic course and frequent relapse of severe infections, such as endocarditis and osteomyelitis [79-81].

\subsection{Intracellular Lifestyle of S. aureus}

\subsubsection{Internalization and Cell Entry}

S. aureus invades a broad range of non-professional phagocytic cells (NPPCs) including epithelial/endothelial cells, osteoblasts, fibroblasts, and keratinocytes, amongst others $[74,82]$. The adhesion and invasion of NPPCs by S. aureus is typically achieved by the well-documented zipper-type mechanism, "FnBP-Fn- $\alpha 5 \beta 1$ integrin-mediated uptake", involving staphylococcal fibronectin-binding proteins A and B (FnBPA and FnBPB) [83,84]. Various cellular pathways are triggered during $S$. aureus binding to host cells, contributing to the endocytosis of the bacterium during cellular invasion. In the model described in Figure 2 of the major internalization pathway involving FnBPA, Fn, and the $\alpha 5 \beta 1$ integrin described by Liang et al. [85], the dimeric host Fn will bind to $\alpha 5 \beta 1$ integrin molecules on the surface of cells. FnBPA repeats bind to Fn and expose $\alpha 5 \beta 1$ binding sites that encourage the clustering of $\alpha 5 \beta 1$ integrins. Clustering of integrins promotes the recruitment of host proteins, including vinculin and tensin, and will additionally promote activation of host focal adhesion kinases (FAKs) and proto-oncogene tyrosine-protein kinase Src (Src) to the bacterial attachment site. The combined activity of FAK and Src results in tyrosine phosphorylation of several host effectors that trigger cytoskeletal rearrangements and the assembly of characteristic endocytic complexes on the intracellular side of the plasma membrane to allow bacterial entry [85]. Alternative staphylococcal host proteins may support the FnBP-Fn- $\alpha 5 \beta 1$ integrin-mediated uptake pathway in certain cell types, including the extracellular adherence protein (Eap), which mediates adhesion and internalization of S. aureus into keratinocytes at various stages of development [86].

While the FnBP-Fn- $\alpha 5 \beta 1$ integrin pathway is historically recognized as the main internalization process, there are numerous "secondary" mechanisms between $S$. aureus virulence factors and host cell components that are involved in or mediate FnBP-independent cellular invasion by $S$. aureus. These mechanisms involve major staphylococcal proteins such as autolysin (Atl), $\alpha$-hemolysin (HLA), clumping factor A (ClfA), clumping factor B (ClfB), iron-regulated surface determinant B (IsdB), lipoprotein-like lipoproteins (Lpls), serine-rich adhesin for platelets (SraP), and bacterial serine aspartate repeat-containing protein $\mathrm{D}(\mathrm{SdrD})$, whose variable interactions with host cell receptors are summarized in Table 3 [87-105]. Further entry pathways are summarized in Figure 3 [106-115]. A thorough summary of the various staphylococcal mechanisms involved in cellular adhesion and invasion is reviewed by Josse et al. [116]. 
1.

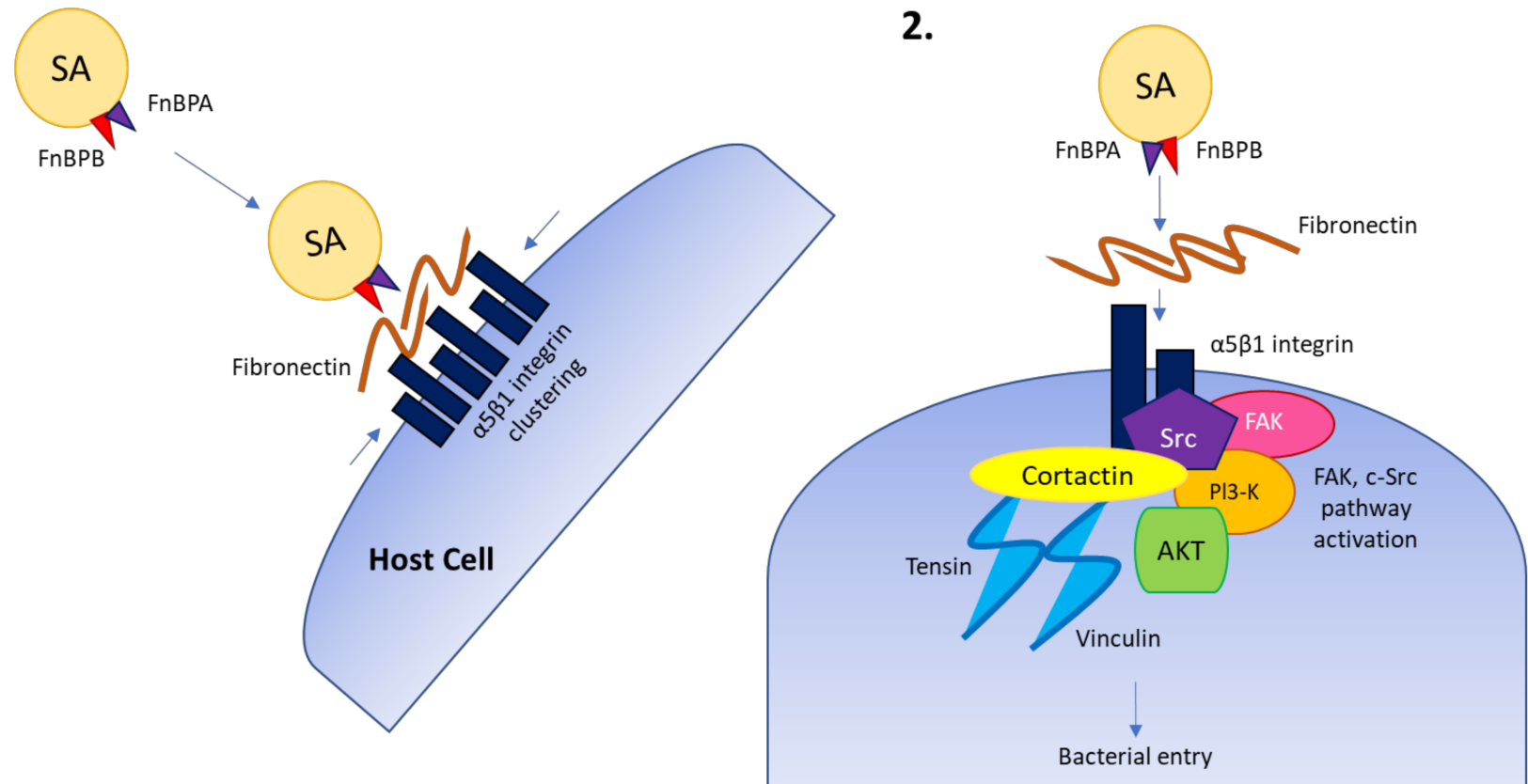

Figure 2. Overview of the zipper-type mechanism or FnBP-Fn- $\alpha 5 \beta 1$ integrin-mediated uptake, involving staphylococcal fibronectin-binding proteins A and B (FnBPA and FnBPB). S. aureus (SA) contains fibronectin-binding proteins A and B (FnBPA and FnBPB) (1). As described by Liang and colleagues [85], these proteins bind to host $\alpha 5 \beta 1$ integrin molecules on the surface of cells (1) where FnBPA repeats bind to Fn and encourage the clustering of $\alpha 5 \beta 1$ integrins. The clustering of integrins promotes the recruitment of host proteins (2), including vinculin and tensin, and will additionally promote activation of host focal adhesion kinases (FAKs) and proto-oncogene tyrosine-protein kinase Src (Src) to the bacterial attachment site. The combined activity of FAK and Src results in tyrosine phosphorylation of several host effectors that trigger cytoskeletal rearrangements and the assembly of characteristic endocytic complexes on the intracellular side of the plasma membrane to allow bacterial entry [85].

Table 3. Alternative staphylococcal secondary mechanisms for cellular attachment and potential entry.

\begin{tabular}{|c|c|c|c|c|}
\hline S. aureus Component & Host Component & Bridge & Host Cell Type & References \\
\hline \multirow[b]{2}{*}{ Atl } & Heat shock cognate & & Keratinocytes & [87] \\
\hline & protein 70 & & Endothelial cells & [88] \\
\hline \multirow{4}{*}{ ClfA } & $\alpha v \beta 3$ integrins & \multirow{3}{*}{ Fibrinogen } & None reported & [89] \\
\hline & & & Vascular endothelial cells & [90] \\
\hline & Annexin A2 & & MAC-T cell & [91] \\
\hline & Von Willebrand Factor & $\begin{array}{l}\text { Von Willebrand } \\
\text { binding protein }\end{array}$ & Endothelial cells & [92-94] \\
\hline \multirow{3}{*}{ ClfB } & Plasma fibrinogen & & & [95] \\
\hline & Cytokeratin 10 & & Desquamated epithelial cells & [96] \\
\hline & Loricrin & & Squamous epithelial cells & {$[97,98]$} \\
\hline \multirow{2}{*}{ IsdB } & $\beta 3$-containing integrins & Extracellular matrix & HEK-293T, HeLa & [99] \\
\hline & $\alpha v \beta 3$ integrins & Vitronectin & Epithelial/endothelial cells & [100] \\
\hline Lpl & Hsp90 & & Keratinocytes & {$[101,102]$} \\
\hline SraP & gp340 & & A549 cells & [103] \\
\hline \multirow{2}{*}{ SdrD } & \multirow{2}{*}{ Desmoglein 1} & & Keratinocytes & [104] \\
\hline & & & Desquamated nasal cells & [105] \\
\hline
\end{tabular}




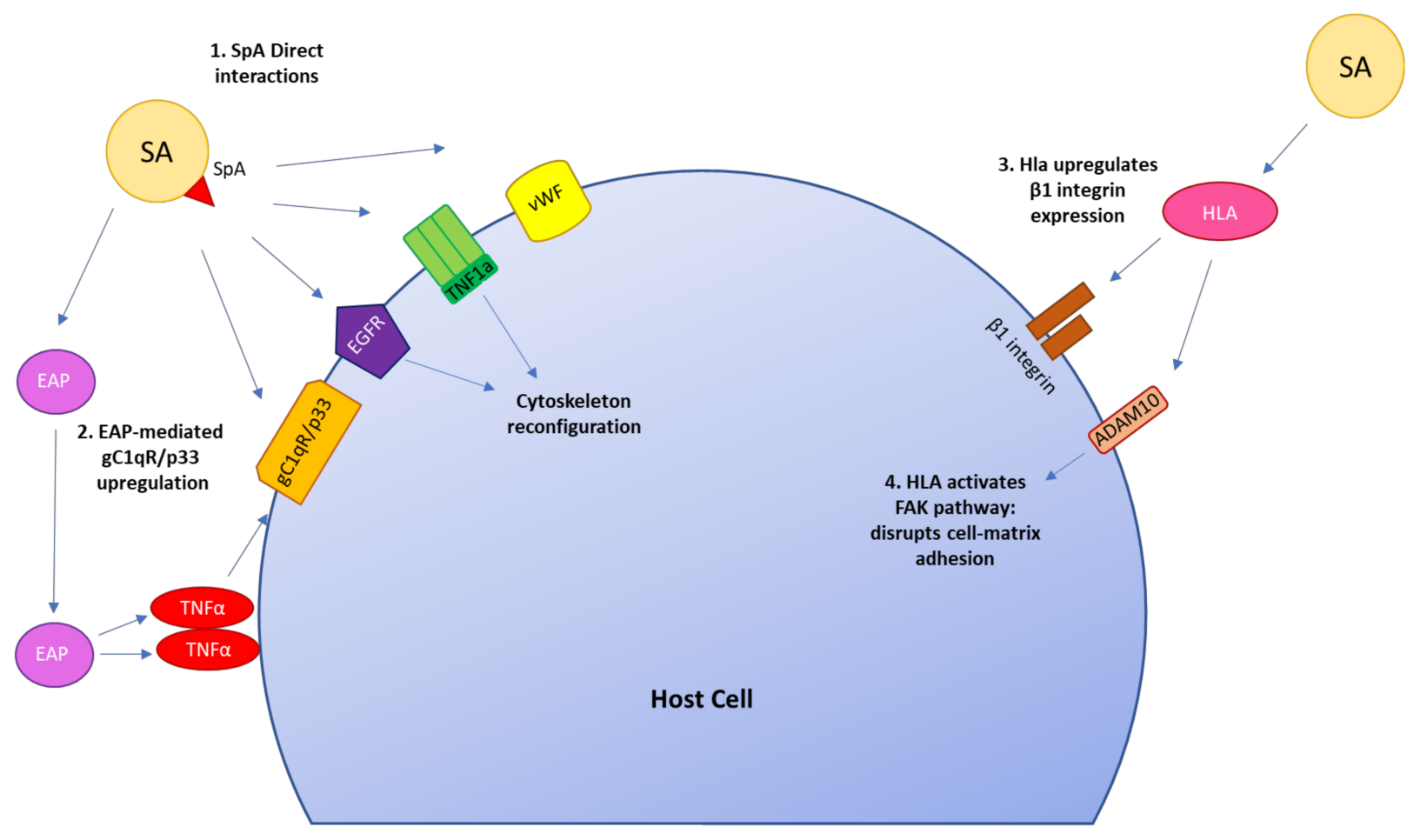

Figure 3. Alternative staphylococcal mechanisms for cellular entry. Staphylococcal protein A (SpA) directly interacts with host tumor necrosis factor $\alpha$ receptor 1 (TNF1a) [106], host receptor gC1qR/p33 on endothelial cells [107], and host vWF in the extracellular matrix of human umbilical vein endothelial cells (1) [108]. SpA has been shown to activate TNF1a and EGF receptor (EGFR) signaling cascades that will re-configure the cytoskeleton for staphylococcal internalization [109,110]. Staphylococcal protein EAP may also enhance attachment of SpA to the endothelium by upregulating host receptor $\mathrm{gC1qR} / \mathrm{p} 33$ on endothelial cells via TNF $\alpha$ release in the bloodstream (2) [107]. S. aureus (SA) has been additionally shown to stimulate its own uptake by upregulating $\beta 1$ integrin expression in the host cell through the secretion of $\alpha$-hemolysin (HLA) (3) [111,112]. S. aureus HLA will disrupt cell-matrix adhesion by activating FAK signaling via interaction with transmembrane protein ADAM10 with the consequent acceleration of focal contact turnover to overcome the defensive barrier function of the airway epithelium (4) [113]. This FAK will also cause plasma membrane depolarization and activates p38 MAP kinase [114]. The $\beta 1$ integrin is additionally involved in transient activation of the phosphatidylinositol 3-kinase/Akt signaling pathway, which might play a crucial role in $\beta 1$ integrin-mediated internalization of S. aureus [115].

Many of the $S$. aureus virulence factors that have been shown to act as both primary and secondary entrance mechanisms are unequally distributed throughout $S$. aureus strains and between the core genome and accessory genomes of those strains [117]. Genomescale models have been created to analyze both the shared and unique virulence factors found between $S$. aureus strains [117]. However, there appears to be a lack of consensus across various genomic investigations regarding which virulence factors are members of the core genome and which are not. For example, as sequencing technology advances, virulence factors that were presumed core genome members have showed greater variation between strains than previously thought. In a study published by Bosi et al. [117] to investigate the conservation of virulence factors across the $S$. aureus strains, the authors selected a set of known virulence factors present in 64 different strains based on literature and database searches. They discovered that multiple virulence factors considered "core genome members" were not found across all 64 strains. Examples of this include protein A (encoded for by spa), which was found in $90 \%$ of strains, and $\alpha$-hemolysin (encoded for by $h l a$ ), found in $96 \%$ of strains [117]. Similarly, Lebughe et al. [118] discovered that hla was detected in $90.3 \%$ of the 186 S. aureus isolates that were paneled [118]. These 
variable findings complicate how to determine which virulence factors may be present within the core genome of S. aureus [118]. A comprehensive list of the percentage of isolates recognized to contain the genes encoding for the primary and secondary mechanisms utilized for cellular entry by $S$. aureus is summarized in Table 4 [117-125], illustrating the broad range of variations that exist across $S$. aureus strains' genomes.

Table 4. Prevalence of genes encoding primary and secondary staphylococcal mechanisms of cellular entry in $S$. aureus isolates genome.

\begin{tabular}{|c|c|c|}
\hline S. aureus Component & $\begin{array}{l}\text { Gene Prevalence in the Investigated } \\
\text { S. aureus Isolates' Genome }\end{array}$ & References \\
\hline Atl & $100 \%$ & [119-122] \\
\hline \multirow{4}{*}{ ClfA } & $100 \%$ & {$[118,119]$} \\
\hline & $87 \%$ & {$[120]$} \\
\hline & $82 \%$ & [121] \\
\hline & $70.4 \%$ & [123] \\
\hline \multirow{2}{*}{ ClfB } & $100 \%$ & {$[119,121]$} \\
\hline & $98 \%$ & [120] \\
\hline \multirow{3}{*}{ Eap } & $100 \%$ & {$[119,124]$} \\
\hline & $99 \%$ & [120] \\
\hline & $45 \%$ & [121] \\
\hline \multirow{2}{*}{ FnBPA } & $100 \%$ & {$[119,120]$} \\
\hline & $99 \%$ & {$[121]$} \\
\hline \multirow{3}{*}{ FnBPB } & $100 \%$ & [119] \\
\hline & $73 \%$ & [121] \\
\hline & $44 \%$ & [120] \\
\hline \multirow{4}{*}{ HLA } & $100 \%$ & {$[120,121,125]$} \\
\hline & $96 \%$ & [117] \\
\hline & $91.9 \%$ & [123] \\
\hline & $90.3 \%$ & [118] \\
\hline \multirow{2}{*}{ IsdB } & $97 \%$ & [121] \\
\hline & $94 \%$ & [120] \\
\hline \multirow{2}{*}{ SpA } & $100 \%$ & {$[120,121]$} \\
\hline & $90 \%$ & [117] \\
\hline \multirow{2}{*}{ SraP } & $100 \%$ & [121] \\
\hline & $43 \%$ & [120] \\
\hline \multirow{3}{*}{ SdrD } & $91 \%$ & [121] \\
\hline & $40 \%$ & [119] \\
\hline & $36 \%$ & [120] \\
\hline
\end{tabular}

\subsubsection{S. aureus Intracellular Survival Strategies}

Once endocytosed by host cells, $S$. aureus can remain there for significant periods of time $[82,84,126,127]$. Indeed, viable bacteria have been recorded inside human endothelial cell lines for up to 10 days after infection and inside THP-1 macrophages up to 7 days [126]. Sinha and Frauholz [84] note that the fates of S. aureus and the survival strategies that it employs to persist in the infected host cell depend on a wide variety of factors that aid in intracellular persistence, including staphylococcal isolate and corresponding virulence factors and differential susceptibility of host cells to virulence factors based upon host cell type and respective gene expression [84].

To remain in professional phagocytes, $S$. aureus must defend against the cell's intracellular antibacterial measures. S. aureus has been shown not only to survive but even to replicate inside the harsh phagosomal environment. S. aureus variably alters the phagosomal acidification process and its eventual fusion with the lysosome, although such interaction is heavily dependent upon the staphylococcal strain and host cell type. The S. aureus-containing 
endosome acquires early endosomal markers such as the small GTPase Rab5 that transition to a Ras-related protein Rab7a and lysosome-associated membrane protein 1 (LAMP1)-associated phagosome that has an acidic intracellular environment [128-131]. This acidification plays a variety of roles in the prolonged survival and replication of $S$. aureus within the cell, with some studies reporting different staphylococcal strategies used to cope with acidification. Acidification in macrophages promotes the expression of the accessory gene regulator (agr) system, an intracellular quorum sensing system of $S$. aureus crucial for the upregulation of numerous virulence factors [131]. Furthermore, intracellular S. aureus will upregulate multiple peptide resistance factor $(\mathrm{MprF})$ through its GraRS system to begin the process of replication within acidified phagolysosomes [132]. Other staphylococcal factors produced to support the de-acidification of the immediate intracellular environment include urease, arginine deiminase, and nitrite/nitrate reductases [130]. The acidification step may be in some cases crucial for $S$. aureus proliferation: the presence of inhibitors of phagosomal acidification was shown to significantly decrease the intracellular survival rates of $S$. aureus in THP-1 macrophages [131]. However, others report an inhibition of acidification or a complete failure of phago-lysosomal development in S. aureus-containing cells [133], as the acidic environment is not achieved due to the lack of production of key host lysosomal hydrolases such as beta-glucuronidase and cathepsin D [131,134]. This may potentially occur via $S$. aureus disruption of beta-glucuronidase and cathepsin D activation [131,134]. Still others have argued that modulation of phagosomal acidification does not affect intracellular survival of $S$. aureus at all [130].

S. aureus additionally recruits or produces multiple factors to deal with the host cell's innate immune response to invasion: genetic factors, including the dlt operon, will encode for proteins responsible for the d-alanylation of teichoic acids in the $S$. aureus membrane. These $S$. aureus proteins provide a physical barrier against host cell defensins and antimicrobial peptides [132]. Multiple peptide resistance factor (MprF) will also confer bacterial resistance against host cationic antimicrobial peptides [132]. Finally, staphyloccocal alternative sigma factor SigB expression contributes to $S$. aureus intracellular persistence by aiding in wildtype $S$. aureus transition to small colony variants (SCVs), which are adapted for longterm intracellular persistence [127]. Other proteins including alpha-toxin, the metalloprotease aureolysin, protein A, and sortase A are also identified as crucial for $S$. aureus persistence in human monocyte-derived macrophages, but their specific roles remain unclear [135].

Extended intracellular persistence of $S$. aureus offers more than a place for replication; in some cases, macrophages may serve as vehicles for the dissemination of infection [135]. $S$. aureus replicates within macrophages during a critical window of time where overexposure to infectious agents has resulted in infected macrophages briefly losing their ability to kill pathogens (termed as "exhausted" macrophages) [134]. S. aureus emerges from these cells via host-cell lysis $[130,131,134,136]$. The emerging $S$. aureus can be phagocytosed again by macrophages to produce a cyclical pattern of uptake and escape that creates a pool of $S$. aureus within macrophages $[128,134,136]$. The survival of $S$. aureus within exhausted macrophages is hypothesized to cause the dissemination of bacteria throughout the host, potentially resulting in deeper and more aggressive infections [134]. This theory has been separately supported by studies employing the intravenous injection of peritoneal macrophages with $S$. aureus to demonstrate higher levels of bacterial dissemination to the kidneys and brain when compared with infections with planktonic bacteria [137]. Surewaard et al. [138] found that captured S. aureus will replicate long-term in liver macrophages, and the eventual release of massive amounts of $S$. aureus from the lysis of dying cells will cause devastating bloodstream infections. Similarly, infected liver neutrophils have been shown to re-enter circulation after infection and disseminate the pathogen to secondary infection sites [139].

\subsubsection{S. aureus Intracellular Escape and Replication}

S. aureus phagosomal escape and subsequent cytoplasmic replication is observed in many non-professional phagocytes such as epithelial cells [129,140], endothelial cells [82,129], 
and keratinocyte lines such as HaCaT or RHEK-1 [82,141]. S. aureus phagosomal escape usually relies upon upregulation of the agr system [141,142], and S. aureus mutants lacking agr will not translocate to the host cell cytoplasm [82]. Agr activity will produce $\alpha$-type phenol-soluble modulins (PSMs), including staphylococcal $\delta$-toxin and PSM $\alpha 1-4$, widely considered key mediators of phagosomal escape in S. aureus strains $[129,143,144]$. Despite their role in $S$. aureus translocation, PSM $\alpha$ production alone is not sufficient for the induction of escape: overexpression of PSM $\alpha$ in escape-deficient $S$. aureus strains did not result in bacterial translocation to the host cytoplasm [140].

Other contributing factors to $S$. aureus escape may include the $\beta$-type PSMs, as proteomic analysis of $S$. aureus strains capable of phagosomal escape has found that these strains produce both PSM $\alpha$ and PSM $\beta$ proteins. Still others additionally upregulate the $\delta$-toxin gene hld [143] or express the phospholipase $\beta$-toxin prior to escape [140]. The inactivation of PSM-specific sm $\alpha$ or ABC-transporter component pmtC reduced phagosomal escape of $S$. aureus $[82,145]$. The production of pore-forming toxins $\alpha$-toxin (Hla) and Panton-Valentine leucocidin (PVL) is critical for escape from some cell types and unneeded for others $[129,141,143,146,147]$. Other staphylococcal proteins such as the Tet38 efflux pump have been shown to be involved in bacterial escape from phagosomes in epithelial cells, but it is still unknown how this interaction mediates escape $[143,148]$. Additional phagosomal escape factors have been identified, including a nonribosomal peptide synthetase (NRPS) complex AusAB in HeLa cells [140].

\subsection{S. aureus Influence over Autophagy and Host Cell Death Pathways}

\subsubsection{Intracellular $S$. aureus Influence over Autophagy}

Autophagy is a degradation procedure responsible for the elimination of unwanted cytoplasmic components and is utilized by the cell to degrade invading pathogens into presentable antigens for host defense [149-151]. S. aureus has been shown to trigger an autophagic response in a wide variety of non-professional phagocytes (NPPCs) as well as dendritic cells, macrophages, and neutrophils [152,153]. S. aureus has been shown to evade host autophagy, and $S$. aureus strains that undergo agr upregulation will block the process of autophagy within dendritic cells, leading to the cytotoxic accumulation of autophagosomes $[128,154]$. Others have reported that such $S$. aureus-containing phagosomes can mature into phagolysosomes without triggering the autophagy pathway [128]. However, some staphylococcal strains were shown to utilize autophagic machinery for survival. Phagocytes will degrade invading microbial threats in LC3-associated phagocytosis (LAP), which combines phagocytic processes with autophagy, resulting in association of microtubule-associated proteins 1A/1B light chain 3 (MAP1LC3) with the phagosomal membrane. The LC3-decorated phagosomes go on to fuse with lysosomes, resulting in enhanced killing and degradation of contained pathogens [155]. The LAP response in macrophages is used as a replication niche for $S$. aureus [152,154,156]. However, even while containing replicating $S$. aureus, these phagosomes still continue to express selective xenophagy receptor $\mathrm{p} 62$ on these phagosomes, which is contrastingly associated with host protection $[153,156]$. Therefore, while the formation of LC3-positive phagosomes facilitates the intracellular replication of $S$. aureus, the retained expression of p62-positive phagosomes represents the host still struggling to eliminate $S$. aureus [156].

Host cell autophagic processes are manipulated by intracellular $S$. aureus in NPPC in multiple ways. However, it remains unclear whether $S$. aureus specifically manipulates autophagy to mitigate host cell defenses or increase its nutrient load or whether it uses autophagic machinery as a replicative niche for increased dissemination. S. aureus releases the $\alpha$-hemolysin (Hla) toxin to trigger the autophagic pathway within NPPC [153,157,158]. However, Hla will activate the host cell inflammasome response [159] through acid sphingomyelinase activity [160], which is detrimental to $S$. aureus. To combat this host-innate immune response, intracellular $S$. aureus develops mutations in the agr regulon (reviewed in Bronesky et al. [161]) that could eliminate production of Hla to decrease inflammasome activation while preserving autophagy. Soong et al. [162] report that $S$. aureus-infected ker- 
atinocytes undergoing induced autophagy displayed lower inflammasome activation and reduced mortality, while inhibition of autophagy resulted in increased cell death levels. The subversion of autophagy to impede programmed cell death (PCD) has also been observed in polymorphonuclear leukocytes, wherein S. aureus is found surviving in autophagosomes and replicating while simultaneously inhibiting apoptosis [163]. Neumann et al. [153] demonstrated the recruitment of selective autophagy receptor proteins such as p62 by murine fibroblasts in response to intracellular infection with $S$. aureus. In response, $S$. aureus activated a strong anti-autophagic response via upregulation of the MAPK14/p38 $\alpha$ MAP kinase-mediated blockade of autophagy, which inhibits fusion with lysosomes to escape degradation [153]. S. aureus did not require autophagosomes to further its development and actively inhibited autophagosomal maturation. A study suggesting yet another alternative benefit for autophagy noted that a significant number of autophagosomes did not contain S. aureus in infected HeLa cells [164]. Instead, S. aureus significantly altered the host metabolic state, simultaneously activating autophagy. By doing so, it began to divert the nutrients generated by this pathway to meet its metabolic needs [154,164]. It was additionally noted in this study that when a reduction in autophagy was observed, S. aureus survival decreased, potentially due to loss of nutrients from alteration of host metabolism. While $S$. aureus likely exploits host cell autophagy, it remains unclear whether this is critical for nutrient uptake, self-defense, the creation of a replication niche, or a combination of all three $[157,165]$.

\subsubsection{Intracellular S. aureus Influence over Host Cell Death}

S. aureus has been identified as manipulating all known principal mechanisms of PCD, including apoptosis and pro-inflammatory pathways necroptosis or pyroptosis, in NPPCs [166-169]. There are multiple potential benefits derived from S. aureus modulation of host cell death. First, controlling the timing and mode of host cell death may help intracellular S. aureus maintain its replicative niche for an extended period of time [168,169]. It can additionally utilize host cell death to penetrate host cell barriers, supporting its dissemination into surrounding tissues [166,167]. Finally, control over host cell death may provide intracellular $S$. aureus with shelter from host immune responses and antibacterial therapies [166].

S. aureus has factors that specifically inhibit apoptosis in NPPCs to delay host cell death and control bacterial exit from host cells [170]. Korea et al. [170] suggested that S. aureus utilizes EsxA, an effector protein secreted by the staphylococcal type VII secretion system, to inhibit apoptosis. This may potentially give the bacterium time to replicate and disseminate into the host tissues [170]. Contrastingly, studies have shown that apoptosis is induced by S. aureus in keratinocytes, as shown by the activation of apoptosis caspases (caspase- $3,-7$, and -8) [171,172]. The trigger for apoptosis in keratinocytes may be the production of PVL, as Chi et al. [141] demonstrated that a PVL-producing S. aureus strain caused significantly more caspase-dependent apoptosis in keratinocytes than a strain lacking PVL production.

S. aureus additionally interacts with pyroptosis pathways in NPPCs. Pyroptosis induction has been shown to be a crucial step required for $S$. aureus penetration through keratinocyte barriers, with Soong et al. [162] suggesting that $S$. aureus may activate pyroptosis of keratinocytes to enhance dissemination [162].

$S$. aureus produces a broad range of pro-PCD virulence factors that may facilitate infiltration of the bacteria into the cells and surrounding tissues, as reviewed previously $[168,173]$, to delay host cell death for increased dissemination or to penetrate host cell barriers. Additionally, other studies note that S. aureus may attempt to prolong NPPC life and avoid triggering these pathways to ensure safety from antibacterial treatment. For example, Kindi et al. [174] noted that S. aureus entered and proliferated within keratinocytes without killing them or triggering any host cell death pathways. The majority of anti-staphylococcal antibiotics at 20-fold their standard minimal inhibitory concentration, including flucloxacillin, teicoplanin, clindamycin, and linezolid, did not kill internalized $S$. aureus during this time. The internalization of $S$. aureus by human skin keratinocytes and 
subsequent lack of host cell death pathway completion in response allowed $S$. aureus to evade killing by most anti-staphylococcal antibiotics in this study [174].

S. aureus may trigger more than one of the above pathways at once: Steltzner et al. [175] suggest that intracellular $S$. aureus disturbs $\mathrm{Ca}^{2+}$ homeostasis and induces cytoplasmic $\mathrm{Ca}^{2+}$ overload in HeLa cells, which results in both apoptotic and mitochondrial permeability transition-driven necrotic cell death occurring simultaneously (or in quick succession). However, they suggest that the damage induced by strong perturbations of the cellular $\mathrm{Ca}^{2+}$ homeostasis and $\mathrm{Ca}^{2+}$ overload may not allow reliable detection of specific signaling pathways. With so many potential interactions between $S$. aureus and PCD pathways, it is difficult to target what the specific pathogenic goal of PCD may be; the damage resulting from this $\mathrm{Ca}^{2+}$ overload may be the reason for much of the conflicting information [175].

Intracellular S. aureus has also been shown to trigger pyroptosis, necroptosis, and other necrotic pathways in THP-1 macrophages, monocytes, and neutrophils, with minimal activation of apoptosis reported in phagosomes of these respective cells [147,176-178]. As seen in NPPC, more than one pathway may be simultaneously activated: Flannagan et al. [128] found that $S$. aureus-infected macrophages showed characteristics of both apoptosis and necrosis [128]. Other studies of S. aureus-infected neutrophils have shown that the cells will undergo morphological changes consistent with apoptosis, before necroptotic RIPK-1dependent lysis occurred [179].

Bacterial control over professional phagocytic cell death is thought to support bacterial dissemination throughout the body as they travel within these mobile cells. Koziel et al. [180] suggested that $S$. aureus maintain human monocyte-derived macrophages for extended periods despite the appearance of early apoptotic features in host cells. S. aureus strongly upregulated the expression of B-cell lymphoma 2 (BCL2) and myeloid cell leukemia 1 (MCL1) genes, which stabilize mitochondrial membrane potential and delay apoptosis. The protective effects of $S$. aureus were confirmed by the finding that $S$. aureus-infected macrophages were more resistant to staurosporine-induced cell death than control cells [180]. Similarly, another study found that intracellular $S$. aureus infection in dendritic cells delayed host cell apoptosis, implicating staphylococcal protein EsxA as a critical mediating factor during this process [181].

\subsection{Summary}

S. aureus has now been recognized as a facultative intracellular pathogen, with its ability to adeptly shift from an extracellular to an intracellular lifestyle playing a crucial role during recurrent and aggressive infections. S. aureus enters a wide range of host cell types and can replicate and survive within host cells, utilizing an incredible range of host cell pathways to enable its survival. As a result of this, effectively eliminating intracellular $S$. aureus remains a major challenge.

\section{Treating Intracellular $P$. aeruginosa and $S$. aureus by Harnessing the Host Immune Response in Combination with Using Antimicrobials}

For a treatment to successfully eradicate intracellular bacterial pathogens, the treatment must overcome several physical barriers due to the location of the pathogens. An obvious treatment strategy would be to enhance and manipulate the host's immune response to the intracellular pathogen, with the most logical treatment choice being a vaccine. Vaccines are one of the most effective strategies for engaging and enhancing the host's natural immune response to prevent and/or eradicate an infection by a pathogen. However, in the case of $S$. aureus and P. aeruginosa, no vaccines are currently available, as discussed below. Additionally, both bacterial species discussed here are listed as species of concern by the WHO due to their AMR, and as discussed above, are both highly adaptable pathogens, common in the environment, and capable of forming biofilms and both have a multitude of virulence factors that can aid in infection, host evasion, and antibiotic resistance/tolerance. Consequently, treating these two pathogens is both challenging and situational, depending 
on the type or location of the infection and the antibiotic tolerance and resistance profile of the specific strains involved [73,182].

Combination therapies show promise for treating these two non-canonical intracellular pathogens, including therapies that combine traditional antimicrobials with treatments that harness the host's immunity. While vaccines are an active immune-based therapy, the use of antibodies or antisera are common passive immune-based therapies. There are many antibody-based treatments that target various antigens from $P$. aeruginosa or S. aureus in various stages of clinical trials, as reviewed in [183-185]. Compared with antibiotic treatments, antibody-based treatments can be expensive due to the amount of protein required per dose, though there are more cost-effective methods available to treat the host with antibodies, such as using DNA-encoded monoclonal antibodies (DMAbs) that are injected into the host's muscle cells, where the antibodies can be made and then circulated to infections sites. DiGiandomenico et al. [186] designed a DMAb that is bispecific and targets PcrV (a protein required for the type III secretion system activity) and PsI (an abundantly expressed exopolysaccharide) from P. aeruginosa. The bispecific DMAb, MEDI3902, showed synergy with the antibiotics ciprofloxacin and tobramycin in mouse models of infections and even at subtherapeutic doses of MEDI3902 with either antibiotic, the combination treatments were effective in preventing death in mice [186]. Unfortunately, MEDI3902 was abandoned in phase II of clinical trials in 2020 [187].

Other antibody-based therapies have shown potential against intracellular $P$. aeruginosa and S. aureus infections. An antibody-antibiotic conjugate (AAC) was constructed by Lehar et al. [137] from Genentech Inc. using monoclonal antibodies (MAbs) against $\beta$ GlcNAc WTA, $\beta$-O-linked N-acetylglucosamine (GlcNAc) sugars on wall-teichoic acids (WTAs), which was linked to the highly effective bactericidal antibiotic rifalogue (a rifampicin derivative) using a cathepsin-cleavable covalent linker. These AACs opsonize S. aureus, and once they are phagocytized, the rifalogue is cleaved from the antibody by endoenzymes within the host cells, and the antibiotic effectively kills intracellular S. aureus, since rifalogue is effective against viable, replicating, and non-replicating bacteria. In vitro and in vivo testing showed this AAC was highly effective at reducing pathogen loads. Additionally, in a mouse infection model, the AAC was more effective at treating S. aureus bacteremia than a traditional treatment with vancomycin antibiotic [137]. Recently, some of these same researchers from Genentech Inc. completed a proof-of-concept study where they engineered an AAC that was effective against $P$. aeruginosa [188]. Building on their previous work, this AAC consisted of MAb 26F8, which binds to lipopolysaccharide $\mathrm{O}$, covalently linked with a lysosomal cathepsin-cleavable linker to the G2637 antibiotic. The AAC, 26F8-cBuCit-G2637, effectively cleared intracellular P. aeruginosa inside macrophages. While demonstrating great in vitro efficacy, unfortunately the 26F8-cBuCit-G2637 AAC was not therapeutically effective in a mouse model of acute $P$. aeruginosa pneumonia, and the researchers suggest that one possible solution to this hindrance could be to use a MAb with stronger opsonic activity to improve the effectiveness in vivo [188].

While the above two examples with AAC-based therapies only passively utilize the host in the therapy against intracellular pathogens, there are some promising new studies that utilize repurposed drugs to directly enhance the host's response to the pathogen in combination with traditional antibiotics. Evans et al. [189] investigated co-treatments of rifampicin with two statin drugs, simvastatin or ML141, against intracellular S. aureus infections. While each statin drug acted on the host and reduced invasion of S. aureus due to reductions in actin stress fiber reordering and fibronectin binding, only the cotreatment of ML141 and rifampicin decreased intracellular S. aureus compared with the rifampicin-alone treatments. Thus, the host-directed therapy of ML141 inhibited bacterial invasion and enhanced rifampicin-killing of S. aureus, as this lipophilic antibiotic is effective against intracellular and extracellular bacteria [189]. A different host-directed therapy strategy was utilized by Xiao et al. [190], as they used the drug memantine (MEM), which is an FDA-approved drug to treat moderate to severe Alzheimer's disease, in combination with the aminoglycoside antibiotic, amikacin (AMK), to treat $P$. aeruginosa and CRPA 
(carbapenem-resistant $P$. aeruginosa) infections in vitro and in vivo. The researchers found that MEM indirectly promoted ROS generation in neutrophils by increasing expression of the p67phox subunit of NADPH oxidase, which enhanced the bactericidal effect of neutrophils against $P$. aeruginosa. Further, MEM was found to be synergistic with AMK, and in vivo experiments showed that the combination therapy reduced the severities of bacteremia and inflammation and that the bacterial burden load was reduced in rats [190].

Host-directed therapies offer the benefit of targeting the host, which greatly reduces the risk of inducing drug resistance in the bacteria. However, the infection environment is complicated, and monotherapies could become ineffective against infections where the bacteria are highly adaptable and have the ability to survive intracellularly, such as what we have described here for the non-canonical intracellular pathogens S. aureus and P. aeruginosa. Several recent encouraging studies have been published on host-directed monotherapies, including: using the kinase inhibitor Ibrutinib to treat intracellular S. aureus [191]; using the sarco/endoplasmic reticulum $\mathrm{Ca}^{2+}$-ATPases (SERCA) inhibitor thapsigargin to treat intracellular S. aureus [192]; treating with the pan-caspase inhibitor quinoline-valine-aspartic acid-difluorophenoxymethyl ketone (Q-VD-OPH) to effectively reduce bacterial skin infections caused by S. aureus, P. aeruginosa, and Streptococcus pyogenes [193]; and utilizing liposomes loaded with phosphatidylinositol 5-phosphate (PI5P), which is involved in actin regulation and vesicular trafficking, to effectively aid macrophage killing of $P$. aeruginosa in a CF model [194]. These host-directed monotherapies offer many possible avenues for treating difficult, persistent bacterial infections, and when these are combined with traditional antibiotic therapies, the outcomes could be enhanced. Ultimately, to combat the growing number of AMR infections worldwide, a multipronged therapy will be required. Thus, there continues to be an urgent need for new therapies to combat AMR infections, and research into combination therapies, including ones that include host-directed therapies, should be a priority to accelerate treatment while slowing the spread of AMR.

\section{Surveillance and Prevention Are Instrumental in Fighting the AMR Crisis}

\subsection{Overview}

Recognizing the full life cycle and niche capabilities in infection caused by P. aeruginosa and $S$. aureus is critical for proper treatment and for reducing the spread of AMR. Additionally, global surveillance and prevention options are essential not only for controlling the infections caused by these two specific priority ESKAPE pathogens but also for controlling the broad spread of AMR in general.

\subsection{Surveillance Is the Cornerstone of $A M R$ Mitigation}

Surveillance lays the groundwork for the control of AMR spread. The WHO Global Antimicrobial Resistance Surveillance System (GLASS) AMR surveillance initiative was launched in 2015 to standardize global reporting of AMR data. The fourth GLASS report published in 2021 [3] included AMR data on over 3 million laboratory-confirmed infections reported in 70 countries. Alarmingly, it was shown that high rates of resistance to both first-line drugs (i.e., co-trimoxazole) and last resort antibiotics (i.e., carbapenems) was observed globally. While it is worth noting that AMR can happen naturally in microbes as a spontaneous phenomenon, the misuse and/or overuse of antimicrobial drugs is the key driver for rapid development and spreading of AMR [195]. An important new development that was highlighted in this 2021 GLASS report was the antimicrobial consumption (AMC) surveillance at the national level. Another key finding from the AMR crisis in the GLASS report was that antimicrobial use in humans continues to increase. Geographical coverage of the GLASS initiative has been continuously expanding: as of May 2021, 109 countries and territories worldwide have enrolled in GLASS [3]. Even as the inaugural issue containing the AMC surveillance data, the 2021 GLASS report included the data reported from 15 out of 19 countries that are enrolled in the AMC module. Nevertheless, broader participation involving countries with different levels of incomes from all regions will facilitate the WHO's mandate of coordinating international efforts to mitigate the impact of 
AMR. For example, India, China, and the USA had the highest antibiotic consumption rate across countries in 2015 according to a report analyzing global antibiotic consumption [196]. In China, two national antimicrobial resistance surveillance networks were established in 2005: The China Antimicrobial Resistance Surveillance System and the China Antimicrobial Surveillance Network publish their summary reports annually [197,198]. Despite some gaps in reporting methodologies in these reports, recent efforts have been undertaken to standardize surveillance on the national level in China $[199,200]$. The inclusion of these data as an integral part of the GLASS initiative will facilitate the concerted actions for global AMR surveillance.

\subsection{The Use of Vaccines Is Critical for Limiting Antimicrobial Use, and Thereby AMR Development}

Limiting the use of antimicrobial drugs is another key component of AMR control. Vaccines for both humans and animals are instrumental in preventing infections and reducing antimicrobial use, therefore limiting the development of resistance. The use of vaccines to fight against infectious diseases is the most significant advance in medical history. As reviewed previously [201], vaccines against viral infections have been widely used (i.e., for measles and influenza) and have gained tremendous success, including the eradication of smallpox and the recently developed revolutionary mRNA vaccines against SARS-CoV-2 [202,203]. Similarly, vaccines targeting bacterial infections have saved countless lives from preventable diseases, such as diphtheria, tetanus, tuberculosis, meningitis, and pneumonia. Table 5 summarizes currently licensed vaccines against bacterial pathogens, which belong to four major different types: inactivated, attenuated, toxoid, and subunit/conjugated. Some of the early vaccines against typhoid fever [204] and cholera [205] belong to the inactivated category, which uses heat- and chemical-killed whole bacterial cells as the main antigen composition. The only inactivated vaccines that are in common usage today are some of the ones used for treating Bordetella pertussis-caused whooping cough [206], while the others are for specific regional use only. For example, the currently licensed inactivated oral cholera vaccines are mostly used within disease endemic regions and for travelers to those regions [207]. The attenuated category uses live whole bacterial cells with abrogated virulence as the vaccine strains. For example, the vaccine strain Bacille Calmette-Guérin (BCG) is a modified Mycobacterium bovis that is still widely used in some regions [208] to elicit a protective response against the closely related Mycobacterium tuberculosis, the causative agent of tuberculosis. Similarly, Salmonella Typhi strain Ty2 $[209,210]$ and Yersinia pestis strain EV76 [211] were used as attenuated vaccine strains for typhoid and plague, respectively. With better understanding of molecular pathogenesis of various pathogens, this vaccination strategy was also exploited for other enteric pathogens, although they were either discontinued (i.e., for Vibrio [212]) or are still under development (i.e., Shigella and enterotoxigenic Escherichia coli $[213,214])$. Other major breakthroughs in vaccine development enabled by our better understanding of infection and immunity mechanisms include toxoid and subunit/conjugated vaccines. The toxoid vaccines, including diphtheria or tetanus toxoid vaccines that are broadly used worldwide, utilize inactivated toxins as antigens when specific toxins instead of the microorganisms cause diseases [215]. The subunit vaccines (also known as acellular vaccines) contain purified fragments from a pathogen, such as proteins or polysaccharides that specifically elicit protective immunity. Examples include vaccines for pertussis (protein subunit), meningitis, and pneumonia (polysaccharide). Some surface polysaccharides can also be fused with a carrier protein in conjugated vaccines to elicit a T cell-dependent longer lasting immunity [216,217]. Despite the tremendous progress in the use of vaccines to prevent bacterial infections, we still lack licensed vaccines for important bacterial pathogens. Examples include the ones that belong to the WHO's AMR priority species, such as methicillin-resistant Staphylococcus aureus [218] and carbapenem-resistant Gram-negative Pseudomonas aeruginosa [219], Acinetobacter baumannii, Klebsiella pneumoniae, and E. coli [220]. Moreover, pathogens that cause sexually transmitted diseases (i.e., Treponema pallidum, Chlamydia, and Neisseria gonorrhoeae) [221,222] are also developing antibiotic resistance. Meanwhile, although many veterinary vaccines 
for livestock are used to control parasitic diseases [223], no licensed vaccines against parasitic or fungal infections are available for human use, despite the large burden of both infection types on global health systems and antimicrobial consumption [224,225].

Table 5. Different types of bacteria vaccines approved for use.

\begin{tabular}{ccc}
\hline Disease(s) & Bacterial Pathogen & Vaccine Type \\
\hline diphtheria & Corynebacterium diphtheriae & toxoid \\
\hline tetanus & Clostridium tetani & toxoid \\
\hline whooping cough & Bordetella pertussis & subunit or inactivated \\
\hline meningitis/pneumonia & Haemophilus influenzae & conjugated \\
\hline meningitis/pneumonia & Streptococcus pneumoniae & subunit or conjugated \\
\hline meningitis & Neisseria meningitidis & subunit or conjugated \\
\hline typhoid fever & Salmonella typhi & attenuated or subunit \\
\hline cholera & Vibrio cholerae & inactivated \\
\hline plague & Yersinia pestis & inactivated \\
\hline anthrax & Bacillus anthracis & subunit \\
\hline tuberculosis & Mycobacterium tuberculosis & attenuated \\
\hline tularemia & Francisella tularensis & attenuated \\
\hline typhus & Rickettsia prowazekii & inactivated \\
\hline Q fever & Coxiella burnetii & inactivated \\
\hline
\end{tabular}

\section{Concluding Remarks}

Excessive use of antibiotics has accelerated the emergence of multidrug-resistant and extensively drug-resistant bacteria, against which even the most effective drugs are ineffective. The $\mathrm{WHO}$ has been sounding the alarm about antimicrobial resistance (AMR) as a severe threat to global health and the global economy $[3,9,226]$. Existing models predict that AMR-associated infections could cause naturally occurring global infectious catastrophes and drive millions of people into extreme poverty. AMR is a highly complex issue, therefore requiring interdisciplinary and multisectoral efforts to better understand and tackle this problem. Better understanding of resistance mechanisms can facilitate the surveillance of AMR emergence and epidemiology and the development of vaccines to prevent and new treatments to treat infections, which are all critical in our battle with the global AMR crisis.

Among the list of these AMR-associated bacteria, carbapenem-resistant P. aeruginosa along with methicillin- and vancomycin-resistant $S$. aureus cause notoriously difficultto-treat recalcitrant infections that are associated with the highest risk of mortality and increased health care costs [227]. Neither of these two species is considered a canonical intracellular bacterium. However, emerging evidence has shown that both P. aeruginosa and $S$. aureus exploit the host intracellular environment actively by the use of multiple virulence factors to promote their intracellular life cycles, potentially contributing to their survival in the presence of antibiotics. This poses an additional challenge to eradicate infections caused by these bacteria, which are already highly resistant to antibiotics. Further research into the mechanisms driving these two bacterial species' intracellular life cycles are desperately needed. Additionally, research in developing novel therapeutics and treatment strategies are urgently needed. In our review, we did not try to exhaustively cover all novel therapies, such as all combination therapies, phage therapies, etc. Instead, we focused on highlighting recent research on therapies that harness the host's immune response, since it is more difficult for the bacteria to develop resistance to the treatment because it is hostdirected. Given the complexity of these intracellular infections, we believe a multifaceted treatment approach will be required to avert catastrophes caused by the increasing number 
of AMR infections worldwide. Using the host's immune response to assist in effectively eradicating the intracellular pathogen will be a key component in slowing the spread of AMR infections, and combining these treatments with traditional antimicrobials has the potential to accelerate patient care and recovery.

Author Contributions: M.K., S.G., R.R. and Z.C. contributed to the writing of the original draft and reviewing and editing the final manuscript. All authors have read and agreed to the published version of the manuscript.

Funding: This work was supported by a Nova Scotia Health Research Foundation Establishment Grant (2018-1536) and a Canadian Institutes of Health Research Project Grant (PJT165970) to Z.C.

Institutional Review Board Statement: Not applicable.

Informed Consent Statement: Not applicable.

Data Availability Statement: Not applicable.

Conflicts of Interest: The authors declare no conflict of interest. The funders had no role in the design of the study; in the collection, analyses, or interpretation of data; in the writing of the manuscript; or in the decision to publish the results.

\section{References}

1. Dong, E.; Du, H.; Gardner, L. An interactive web-based dashboard to track COVID-19 in real time. Lancet Inf. Dis. 2020, 20 , 533-534. [CrossRef]

2. Adalja, A.A.; Watson, M.; Toner, E.S.; Cicero, A.; Inglesby, T.V. Characteristics of microbes most likely to cause pandemics and global catastrophes. Curr. Top. Microbiol. Immunol. 2019, 424, 1-20. [CrossRef] [PubMed]

3. Global Antimicrobial Resistance and Use Surveillance System (GLASS) Report 2021; Licence: CC BY-NC-SA 3.0 IGO; World Health Organization: Geneva, Switzerland, 2021.

4. Nadimpalli, M.L.; Chan, C.W.; Doron, S. Antibiotic resistance: A call to action to prevent the next epidemic of inequality. Nat. Med. 2021, 27, 187-188. [CrossRef] [PubMed]

5. Pelfrene, E.; Botgros, R.; Cavaleri, M. Antimicrobial multidrug resistance in the era of COVID-19: A forgotten plight? Antimicrob. Resist. Infect. Control 2021, 10, 21. [CrossRef]

6. Knight, G.M.; Glover, R.E.; McQuaid, C.F.; Olaru, I.D.; Gallandat, K.; Leclerc, Q.J.; Fuller, N.M.; Willcocks, S.J.; Hasan, R.; van Kleef, E.; et al. Antimicrobial resistance and COVID-19: Intersections and implications. eLife 2021, 10, e64139. [CrossRef]

7. May, M. Tomorrow's biggest microbial threats. Nat. Med. 2021, 27, 358-359. [CrossRef]

8. Cars, O.; Chandy, S.J.; Mpundu, M.; Peralta, A.Q.; Zorzet, A.; So, A.D. Resetting the agenda for antibiotic resistance through a health systems perspective. Lancet Glob. Health 2021, 9, e1022-e1027. [CrossRef]

9. World Health Organization. Fact Sheets-Antimicrobial resistance. Available online: https://www.who.int/news-room/factsheets/detail/antimicrobial-resistance (accessed on 17 November 2021).

10. Gandra, S.; Barter, D.M.; Laxminarayan, R. Economic burden of antibiotic resistance: How much do we really know? Clin. Microbiol. 2014, 20, 973-980. [CrossRef]

11. Phiri, A.; Abia, A.; Amoako, D.G.; Mkakosya, R.; Sundsfjord, A.; Essack, S.Y.; Simonsen, G.S. Burden, Antibiotic resistance, and clonality of Shigella spp. Implicated in community-acquired acute diarrhoea in Lilongwe, Malawi. Trop. Med. Infect. Dis. 2021, 6, 63. [CrossRef]

12. Zhen, X.; Stålsby Lundborg, C.; Sun, X.; Zhu, N.; Gu, S.; Dong, H. Economic burden of antibiotic resistance in China: A national level estimate for inpatients. Antimicrob. Resist. Infect. Control 2021, 10, 5. [CrossRef]

13. Woolhouse, M.; Waugh, C.; Perry, M.R.; Nair, H. Global disease burden due to antibiotic resistance-State of the evidence. J. Glob. Health 2016, 6, 010306. [CrossRef]

14. de Kraker, M.E.; Davey, P.G.; Grundmann, H.; BURDEN Study Group. Mortality and hospital stay associated with resistant Staphylococcus aureus and Escherichia coli bacteremia: Estimating the burden of antibiotic resistance in Europe. PLoS Med. 2011, 8, e1001104. [CrossRef]

15. Zhen, X.; Lundborg, C.S.; Sun, X.; Hu, X.; Dong, H. Economic burden of antibiotic resistance in ESKAPE organisms: A systematic review. Antimicrob. Resist. Infect. Control 2019, 8, 137. [CrossRef]

16. Teillant, A.; Gandra, S.; Barter, D.; Morgan, D.J.; Laxminarayan, R. Potential burden of antibiotic resistance on surgery and cancer chemotherapy antibiotic prophylaxis in the USA: A literature review and modelling study. Lancet Infect. Dis. 2015, 15, 1429-1437. [CrossRef]

17. O'Neill, J. Review on antimicrobial resistance: Tackling a crisis for the health and wealth of nations. London: The Review on Antimicrobial Resistance chaired by Jim O’Neill. 2014. Available online: https://wellcomecollection.org/works/rdpck35v/items (accessed on 17 November 2021).

18. Murray, C.J.; Ikuta, K.S.; Sharara, F.; Swetschinski, L.; Aguilar, G.R.; Gray, A.; Han, C.; Bisignano, C.; Rao, P.; Wool, E.; et al. Global burden of bacterial antimicrobial resistance in 2019: A systematic analysis. Lancet 2022; ahead of print. [CrossRef] 
19. Ehrlich, P.; Halta, S. Die Experimentelle Chemotherapie der Spirillosen; Springer: Berlin, Germany, 1910.

20. Fleming, A. On the antibacterial action of cultures of a penicillium, with special reference to their use in the isolation of $B$. influenzæ. Br. J. Exp. Pathol. 1929, 10, 226-236. [CrossRef]

21. Chain, E.; Florey, H.W.; Gardner, A.D.; Heatley, N.G.; Jennings, M.A.; Orr-Ewing, J.; Sanders, A.G. THE CLASSIC: Penicillin as a chemotherapeutic agent. 1940. Clin. Orth. Relat. Res. 2005, 439, 23-26. [CrossRef]

22. Aminov, R.I. A brief history of the antibiotic era: Lessons learned and challenges for the future. Front Microbiol. $2010,1,134$. [CrossRef]

23. Reygaert, W.C. An overview of the antimicrobial resistance mechanisms of bacteria. AIMS Microbiol 2018, 4, 482-501. [CrossRef]

24. Silva, M.T.; Pestana, N.T. The in vivo extracellular life of facultative intracellular bacterial parasites: Role in pathogenesis. Immunobiology 2013, 218, 325-337. [CrossRef]

25. Kamaruzzaman, N.F.; Kendall, S.; Good, L. Targeting the hard to reach: Challenges and novel strategies in the treatment of intracellular bacterial infections. Br. J. Pharm. 2017, 174, 2225-2236. [CrossRef] [PubMed]

26. Tulkens, P.M. Intracellular distribution and activity of antibiotics. Eur. J. Clin. Microbiol. Infect. Dis. 1991, 10, 100-106. [CrossRef] [PubMed]

27. Nagai, J.; Takano, M. Molecular aspects of renal handling of aminoglycosides and strategies for preventing the nephrotoxicity. Drug Metab. Pharm. 2004, 19, 159-170. [CrossRef] [PubMed]

28. Grant, S.S.; Hung, D.T. Persistent bacterial infections, antibiotic tolerance, and the oxidative stress response. Virulence 2013, 4, $273-283$. [CrossRef]

29. Nguyen, H.A.; Denis, O.; Vergison, A.; Theunis, A.; Tulkens, P.M.; Struelens, M.J.; Van Bambeke, F. Intracellular activity of antibiotics in a model of human THP-1 macrophages infected by a Staphylococcus aureus small-colony variant strain isolated from a cystic fibrosis patient: Pharmacodynamic evaluation and comparison with isogenic normal-phenotype and revertant strains. Antimicrob. Agents Chemother. 2009, 53, 1434-1442. [CrossRef]

30. Rao, M.; Ippolito, G.; Mfinanga, S.; Ntoumi, F.; Yeboah-Manu, D.; Vilaplana, C.; Zumla, A.; Maeurer, M. Latent TB Infection (LTBI)—Mycobacterium tuberculosis pathogenesis and the dynamics of the granuloma battleground. Int. J. Infect. Dis. 2019, 80, S58-S61. [CrossRef]

31. Bhatt, K.; Salgame, P. Host innate immune response to Mycobacterium tuberculosis. J. Clin. Immunol. 2007, 27, 347-362. [CrossRef]

32. Wolf, A.J.; Desvignes, L.; Linas, B.; Banaiee, N.; Tamura, T.; Takatsu, K.; Ernst, J.D. Initiation of the adaptive immune response to Mycobacterium tuberculosis depends on antigen production in the local lymph node, not the lungs. J. Exp. Med. 2008, 205, 105-115. [CrossRef]

33. Wayne, L.G.; Sohaskey, C.D. Nonreplicating persistence of Mycobacterium tuberculosis. Annu. Rev. Microbiol. 2001, 55, 139-163. [CrossRef]

34. Stover, C.; Phamm, X.; Erwin, A.; Mizoguchi, S.D.; Warrener, P.; Hickey, M.J.; Brinkman, F.S.; Hufnagle, W.O.; Kowalik, D.J.; Lagrou, M.; et al. Complete genome sequence of Pseudomonas aeruginosa PAO1, an opportunistic pathogen. Nature 2000, 406, 959-964. [CrossRef]

35. Lyczak, J.B.; Cannon, C.L.; Pier, G.B. Establishment of Pseudomonas aeruginosa infection: Lessons from a versatile opportunist. Microbes Infect. 2000, 2, 1051-1060. [CrossRef]

36. Alonso, B.; Fernández-Barat, L.; Di Domenico, E.G.; Marín, M.; Cercenado, E.; Merino, I.; de Pablos, M.; Muñoz, P.; Guembe, M. Correction to: Characterization of the virulence of Pseudomonas aeruginosa strains causing ventilator-associated pneumonia. BMC Infect. Dis. 2000, 20, 951. [CrossRef] [PubMed]

37. Bleves, S.; Viarre, V.; Salacha, R.; Michel, G.P.F.; Filloux, A.; Voulhoux, R. Protein secretion systems in Pseudomonas aeruginosa: A wealth of pathogenic weapons. Int. J. Med. Microbiol. 2010, 300, 534-543. [CrossRef] [PubMed]

38. Pang, Z.; Raudonis, R.; Glick, B.R.; Lin, T.; Cheng, Z. Antibiotic resistance in Pseudomonas aeruginosa: Mechanisms and alternative therapeutic strategies. Biotechnol. Adv. 2019, 37, 177-192. [CrossRef]

39. Lambert, P.A. Mechanisms of antibiotic resistance in Pseudomonas aeruginosa. J. R. Soc. Med. 2002, 95, $22-26$.

40. Drenkard, E. Antimicrobial resistance of Pseudomonas aeruginosa biofilms. Microbes Infect. 2003, 5, 1213-1219. [CrossRef]

41. Klockgether, J.; Cramer, N.; Wiehlmann, L.; Davenport, C.F.; Tümmler, B. Pseudomonas aeruginosa genomic structure and diversity. Front. Microbiol. 2011, 2, 150. [CrossRef]

42. Poulsen, B.E.; Yang, R.; Clatworthy, A.E.; White, T.; Osmulski, S.J.; Li, L.; Penaranda, C.; Lander, E.S.; Shoresh, N.; Hung, D.T. Defining the core essential genome of Pseudomonas aeruginosa. Proc. Natl. Acad. Sci. USA 2019, 116, 10072-10080. [CrossRef]

43. Subedi, D.; Vijay, A.K.; Kohli, G.S.; Rice, S.A.; Willcox, M. Comparative genomics of clinical strains of Pseudomonas aeruginosa strains isolated from different geographic sites. Sci. Rep. 2018, 8, 15668. [CrossRef]

44. Weiser, R.; Green, A.E.; Bull, M.J.; Cunningham-Oakes, E.; Jolley, K.A.; Maiden, M.C.J.; Hall, A.J.; Winstanley, C.; Weightman, A.J.; Donoghue, D.; et al. Not all Pseudomonas aeruginosa are equal: Strains from industrial sources possess uniquely large mutlireplicon genomes. Microb. Genom. 2019, 5, e000276. [CrossRef]

45. Sana, T.G.; Baumann, C.; Merdes, A.; Soscia, C.; Rattei, T.; Hachani, A.; Jones, C.; Bennett, K.L.; Filloux, A.; Superti-Furga, G.; et al. Internalization of Pseudomonas aeruginosa strain PAO1 into epithelial cells is promoted by interaction of a T6SS effector with the microtubule network. MBio 2015, 6, e00712-e00715. [CrossRef] [PubMed]

46. Penaranda, C.; Chumbler, N.M.; Hung, D.T. Dual transcriptional analysis reveals adaptation of host and pathogen to intracellular survival of Pseudomonas aeruginosa associated with urinary tract infection. PLoS Pathog. 2015, 17, e1009534. [CrossRef] [PubMed] 
47. Angus, A.A.; Lee, A.A.; Augustin, D.K.; Lee, E.J.; Evans, D.J.; Fleiszig, S.M. Pseudomonas aeruginosa induces membrane blebs in epithelial cells, which are utilized as a niche for intracellular replication and motility. Infect. Immun. 2008, 76, 1992-2001. [CrossRef] [PubMed]

48. Garcia-Medina, R.; Dunne, W.M.; Singh, P.K.; Brody, S.L. Pseudomonas aeruginosa acquires biofilm-like properties within airway epithelial cells. Infect. Immun. 2005, 73, 8298-8305. [CrossRef]

49. Sana, T.G.; Hachani, A.; Bucior, I.; Soscia, C.; Garvis, S.; Termine, E.; Engel, J.; Filloux, A.; Bleves, S. The second type VI secretion system of Pseudomonas aeruginosa strain PAO1 is regulated by quorum sensing and fur and modulates internalization in epithelial cells. J. Biol. Chem. 2012, 287, 27095-27105. [CrossRef]

50. Angus, A.A.; Evans, D.J.; Barbieri, J.T.; Fleiszig, S.M. The ADP-ribosylation domain of Pseudomonas aeruginosa ExoS is required for membrane bleb niche formation and bacterial survival within epithelial cells. Infect. Immun. 2010, 78, 4500-4510. [CrossRef]

51. Garai, P.; Berry, L.; Moussouni, M.; Bleves, S.; Blanc-Potard, A.-B. Killing from the Inside: Intracellular role of T3SS in the fate of Pseudomonas aeruginosa within macrophages revealed by MgtC and OprF mutants. PLoS Pathog. 2019, 15, e1007812. [CrossRef]

52. Kierbel, A.; Gassama-Diagne, A.; Mostov, K.; Engel, J.N. The phosphoinositol-3-kinase-protein Kinase B/Akt pathway is Critical for Pseudomonas aeruginosa strain PAK internalization. Mol. Biol. Cell 2005, 16, 2577-2585. [CrossRef]

53. Kierbel, A.; Gassama-Diagne, A.; Rocha, C.; Radoshevich, L.; Olson, J.; Mostov, K.; Engel, J. Pseudomonas aeruginosa exploits a PIP3-dependent pathway to transform apical into basolateral membrane. J. Cell Biol. 2007, 177, 21-27. [CrossRef]

54. Durand, E.; Cambillau, C.; Cascales, E.; Journet, L. VgrG, Tae, Tle, and beyond: The versatile arsenal of type VI secretion effectors. Trends Microbiol. 2014, 22, 498-507. [CrossRef]

55. Kollman, J.M.; Merdes, A.; Mourey, L.; Agard, D.A. Microtubule nucleation by $\gamma$-tubulin complexes. Nat. Rev. Mol. Cell Biol. 2011, 12, 709-721. [CrossRef] [PubMed]

56. Wolfgang, M.C.; Kulasekara, B.R.; Liang, X.; Boyd, D.; Wu, K.; Yang, Q.; Miyada, C.G.; Lory, S. Conservation of genome content and virulence determinants among clinical and environmental isolates of Pseudomonas aeruginosa. Proc. Natl. Acad. Sci. USA 2003, 100, 8484-8489. [CrossRef] [PubMed]

57. Yahr, T.L.; Vallis, A.J.; Hancock, M.K.; Barbieri, J.T.; Frank, D.W. ExoY, an adenylate cyclase secreted by the Pseudomonas aeruginosa type III system. Proc. Natl. Acad. Sci. USA 1998, 95, 13899-13904. [CrossRef] [PubMed]

58. Barbieri, J.T.; Sun, J. Pseudomonas aeruginosa ExoS and ExoT. In Reviews of Physiology, Biochemistry and Pharmacology; Aktories, K., Just, I., Eds.; Springer: Berlin, Germany, 2004; Volume 152, pp. 79-92.

59. Lee, V.T.; Smith, R.S.; Tümmler, B.; Lory, S. Activities of Pseudomonas aeruginosa effectors secreted by the type III secretion system in vitro and during infection. Infect. Immun. 2005, 73, 1695-1705. [CrossRef] [PubMed]

60. Kroken, A.R.; Chen, C.K.; Evans, D.J.; Yahr, T.L.; Fleiszig, S.M. The impact of ExoS on Pseudomonas aeruginosa internalization by epithelial cells is independent of FleQ and correlates with bistability of type three secretion system gene expression. MBio 2018, 9 , e00668-e00718. [CrossRef]

61. Borkar, D.S.; Acharya, N.R.; Leong, C.; Lalitha, P.; Srinivasan, M.; Oldenburg, C.E.; Cevallos, V.; Lietman, T.M.; Evans, D.J.; Fleiszig, S.M. Cytotoxic clinical isolates of Pseudomonas aeruginosa identified during the steroids for corneal ulcers trial show elevated resistance to fluoroquinolones. BMC Ophthalmol. 2014, 14, 54. [CrossRef]

62. Fleiszig, S.M.; Wiener-Kronish, J.P.; Miyazaki, H.; Vallas, V.; Mostov, K.E.; Kanada, D.; Sawa, T.; Yen, T.S.; Frank, D.W. Pseudomonas aeruginosa-mediated cytotoxicity and invasion correlate with distinct genotypes at the loci encoding exoenzymes. Infect. Immun. 1997, 65, 579-586. [CrossRef]

63. Heimer, S.R.; Evans, D.J.; Stern, M.E.; Barbieri, J.T.; Yahr, T.; Fleiszig, S.M. Pseudomonas aeruginosa utilizes the type III secreted toxin ExoS to avoid acidified compartments within epithelial cells. PLoS ONE 2013, 8, e73111. [CrossRef]

64. Belon, C.; Soscia, C.; Bernut, A.; Laubier, A.; Bleves, S.; Blanc-Potard, A.-B. A macrophage subversion factor is shared by intracellular and extracellular pathogens. PLoS Pathog. 2015, 11, e1004969. [CrossRef]

65. Liu, T.; Zhang, L.; Joo, D.; Sun, S.-C. NF-KB signaling in inflammation. Sig. Transduct. Target. 2017, 2, 17023. [CrossRef]

66. Williamson, K.S.; Richards, L.A.; Perez-Osorio, A.C.; Pitts, B.; McInnerney, K.; Stewart, P.S.; Franklin, M.J. Heterogeneity in Pseudomonas aeruginosa biofilms includes expression of hibernation factors in the antibiotic-tolerant subpopulation and Hypoxia-induced stress response in the metabolically active population. J. Bacteriol. 2012, 194, 2062-2073. [CrossRef] [PubMed]

67. Mulcahy, L.R.; Burns, J.L.; Lory, S.; Lewis, K. Emergence of Pseudomonas aeruginosa strains producing high levels of persister cells in patients with cystic fibrosis. J. Bacteriol. 2010, 192, 6191-6199. [CrossRef]

68. Maisonneuve, E.; Gerdes, K. Molecular mechanisms underlying bacterial persisters. Cell 2014, 157, 539-548. [CrossRef] [PubMed]

69. Schulte, M.; Olschewski, K.; Hensel, M. The protected physiological status of intracellular Salmonella enterica persisters reduces host cell-imposed stress. Commun. Biol. 2020, 4, 520. [CrossRef] [PubMed]

70. Bakkeren, E.; Huisman, J.S.; Fattinger, S.A.; Hausmann, A.; Furter, M.; Egli, A.; Slack, E.; Sellin, M.E.; Bonhoeffer, S.; Regoes, R.R.; et al. Salmonella persisters promote the spread of antibiotic resistance plasmids in the gut. Nature 2019, 573, 276-280. [CrossRef] [PubMed]

71. Anyanwu, N.J.; John, W.C. Conventional and Rapid Methods for Identification of Staphylococcus Aureus from Clinical Specimens. Sci. J. Microbiol. 2013, 2, 174-178. [CrossRef]

72. Sakr, A.; Brégeon, F.; Mège, J.-L.; Rolain, J.-M.; Blin, O. Staphylococcus aureus nasal colonization: An update on mechanisms, epidemiology, risk factors, and subsequent infections. Front. Microbiol. 2018, 9, 2419. [CrossRef] 
73. Tong, S.Y.; Davis, J.S.; Eichenberger, E.; Holland, T.L.; Fowler, V.G. Staphylococcus aureus infections: Epidemiology, pathophysiology, clinical manifestations, and management. Clin. Microbiol. Rev. 2015, 28, 603-661. [CrossRef]

74. Yang, X.; Guo, R.; Xie, B.; Lai, Q.; Xu, J.; Hu, N.; Wan, L.; Dai, M.; Zhang, B. Drug resistance of pathogens causing nosocomial infection in orthopedics from 2012 to 2017: A 6-year retrospective study. J. Orthop. Surg. Res. 2021, 16, 100. [CrossRef]

75. Casadevall, A.; Fang, F.C. The intracellular pathogen concept. Mol. Microbiol. 2020, 113, 541-545. [CrossRef]

76. Horn, J.; Stelzner, K.; Rudel, T.; Fraunholz, M. Inside job: Staphylococcus aureus host-pathogen interactions. Int. J. Microbiol. 2018, 308, 607-624. [CrossRef] [PubMed]

77. Lowy, F.D. Is Staphylococcus aureus an intracellular pathogen? Trends Microbiol. 2000, 8, 341-343. [CrossRef]

78. Kwiecinski, J.M.; Horswill, A.R. Staphylococcus aureus bloodstream infections: Pathogenesis and regulatory mechanisms. Curr. Opin. Microbiol. 2020, 53, 51-60. [CrossRef] [PubMed]

79. Alder, K.D.; Lee, I.; Munger, A.M.; Kwon, H.-K.; Morris, M.T.; Cahill, S.V.; Back, J.H.; Yu, K.E.; Lee, F.Y. Intracellular Staphylococcus aureus in bone and joint infections: A mechanism of disease recurrence, inflammation, and bone and cartilage destruction. Bone 2020, 141, 115568. [CrossRef]

80. Loss, G.; Simões, P.M.; Valour, F.; Cortês, M.F.; Gonzaga, L.; Bergot, M.; Trouillet-Assant, S.; Josse, J.; Diot, A.; Ricci, E.; et al. Staphylococcus aureus small colony variants (SCVs): News from a chronic prosthetic joint infection. Front. Cell. Infect. Microbiol. 2019, 9, 363. [CrossRef]

81. Oberbach, A.; Schlichting, N.; Feder, S.; Lehmann, S.; Kullnick, Y.; Buschmann, T.; Blumert, C.; Horn, F.; Neuhaus, J.; Neujahr, R.; et al. New insights into valve-related intramural and intracellular bacterial diversity in infective endocarditis. PLoS ONE 2017, 12, e0175569. [CrossRef]

82. Strobel, M.; Pförtner, H.; Tuchscherr, L.; Völker, U.; Schmidt, F.; Kramko, N.; Schnittler, H.-J.; Fraunholz, M.J.; Löffler, B.; Peters, G.; et al. Post-invasion events after infection with Staphylococcus aureus are strongly dependent on both the host cell type and the infecting S. aureus strain. Clin. Microbiol. Infect. 2016, 22, 799-809. [CrossRef]

83. Edwards, A.M.; Potter, U.; Meenan, N.A.; Potts, J.R.; Massey, R.C. Staphylococcus aureus keratinocyte invasion is dependent upon multiple high-affinity fibronectin-binding repeats within FnBPA. PLoS ONE 2011, 6, e18899. [CrossRef]

84. Fraunholz, M.; Sinha, B. Intracellular Staphylococcus aureus: Live-in and let die. Front. Cell Infect. Microbiol. 2012, 2, 43. [CrossRef]

85. Liang, X.; Garcia, B.L.; Visai, L.; Prabhakaran, S.; Meenan, N.A.; Potts, J.R.; Humphries, M.J.; Höök, M. Allosteric regulation of fibronectin / $\alpha 5 \beta 1$ interaction by fibronectin-binding mscramms. PLoS ONE 2016, 11, e0159118. [CrossRef]

86. Bur, S.; Preissner, K.T.; Herrmann, M.; Bischoff, M. The Staphylococcus aureus extracellular adherence protein promotes bacterial internalization by keratinocytes independent of fibronectin-binding proteins. J. Investig. Dermatol. 2013, 133, 2004-2012. [CrossRef] [PubMed]

87. Hirschhausen, N.; Schlesier, T.; Schmidt, M.A.; Götz, F.; Peters, G.; Heilmann, C. A novel staphylococcal internalization mechanism involves the major autolysin atl and heat shock cognate protein HSC70 as host cell receptor. Cell Microbiol. 2010, 12, 1746-1764. [CrossRef] [PubMed]

88. Schlesier, T.; Siegmund, A.; Rescher, U.; Heilmann, C. Characterization of the ATL-mediated staphylococcal internalization mechanism. Int. J. Med. Microbiol. Suppl. 2020, 310, 151463. [CrossRef] [PubMed]

89. Herman-Bausier, P.; Labate, C.; Towell, A.M.; Derclaye, S.; Geoghegan, J.A.; Dufrêne, Y.F. Staphylococcus aureus clumping factor A is a force-sensitive molecular switch that activates bacterial adhesion. Proc. Natl. Acad Sci. USA 2018, 115, 5564-5569. [CrossRef] [PubMed]

90. McDonnell, C.J.; Garciarena, C.D.; Watkin, R.L.; McHale, T.M.; McLoughlin, A.; Claes, J.; Verhamme, P.; Cummins, P.M.; Kerrigan, S.W. Inhibition of major integrin $\alpha \mathrm{v} \beta 3$ reduces Staphylococcus aureus attachment to sheared human endothelial cells. J. Thromb. Haemost. 2016, 14, 2536-2547. [CrossRef]

91. Ashraf, S.; Cheng, J.; Zhao, X. Clumping factor A of staphylococcus aureus interacts with annexin A2 on mammary epithelial cells. Sci. Rep. 2017, 7, 40608. [CrossRef]

92. Claes, J.; Liesenborghs, L.; Peetermans, M.; Veloso, T.R.; Missiakas, D.; Schneewind, O.; Mancini, S.; Entenza, J.M.; Hoylaerts, M.F.; Heying, R.; et al. Clumping factor A, von Willebrand factor-binding protein and von willebrand factor anchor Staphylococcus aureus to the vessel wall. J. Thromb. Haemost. 2017, 15, 1009-1019. [CrossRef]

93. Na, M.; Hu, Z.; Mohammad, M.; do Stroparo, M.; Ali, A.; Fei, Y.; Jarneborn, A.; Verhamme, P.; Schneewind, O.; Missiakas, D.; et al. The expression of von Willebrand factor-binding protein determines joint-invading capacity of Staphylococcus aureus, a core mechanism of septic arthritis. Mbio 2020, 11, e02472-20. [CrossRef]

94. Viljoen, A.; Viela, F.; Mathelié-Guinlet, M.; Missiakas, D.; Pietrocola, G.; Speziale, P.; Dufrêne, Y.F. Staphylococcus aureus vWFbinding protein triggers a strong interaction between clumping factor A and host vWF. Commun. Biol. 2021, 4, 453. [CrossRef]

95. Walsh, E.J.; Miajlovic, H.; Gorkun, O.V.; Foster, T.J. Identification of the Staphylococcus aureus MSCRAMM clumping factor B (clfb) binding site in the $\alpha$ C-domain of human fibrinogen. Microbiology 2008, 154, 550-558. [CrossRef]

96. Walsh, E.J.; O’Brien, L.M.; Liang, X.; Hook, M.; Foster, T.J. Clumping factor B, a fibrinogen-binding MSCRAMM (microbial surface components recognizing adhesive matrix molecules) adhesin of Staphylococcus aureus, also binds to the tail region of type I cytokeratin 10. J. Biol. Chem. 2004, 279, 50691-50699. [CrossRef] [PubMed]

97. Mulcahy, M.E.; Geoghegan, J.A.; Monk, I.R.; O'Keeffe, K.M.; Walsh, E.J.; Foster, T.J.; McLoughlin, R.M. Nasal colonisation by Staphylococcus aureus depends upon clumping factor B binding to the squamous epithelial cell envelope protein loricrin. PLoS Pathog. 2012, 8, e1003092. [CrossRef] [PubMed] 
98. Vitry, P.; Valotteau, C.; Feuillie, C.; Bernard, S.; Alsteens, D.; Geoghegan, J.A.; Dufrêne, Y.F. Force-induced strengthening of the interaction between staphylococcus aureus clumping factor B and loricrin. Mbio 2017, 8, e01748-17. [CrossRef] [PubMed]

99. Zapotoczna, M.; Jevnikar, Z.; Miajlovic, H.; Kos, J.; Foster, T.J. Iron-regulated surface determinant B (ISDB) Promotes staphylococcus aureus adherence to and internalization by non-phagocytic human cells. Cell Microbiol. 2013, 15, 1026-1041. [CrossRef]

100. Pietrocola, G.; Pellegrini, A.; Alfeo, M.J.; Marchese, L.; Foster, T.J.; Speziale, P. The iron-regulated surface determinant B (ISDB) protein from Staphylococcus aureus acts as a receptor for the host protein vitronectin. J. Biol. Chem. 2020, 295, 10008-10022. [CrossRef]

101. Nguyen, M.-T.; Luqman, A.; Bitschar, K.; Hertlein, T.; Dick, J.; Ohlsen, K.; Bröker, B.; Schittek, B.; Götz, F. Staphylococcal (phospho)lipases promote biofilm formation and host cell invasion. Int. J. Med. Microbiol. Suppl. 2018, 308, 653-663. [CrossRef]

102. Tribelli, P.M.; Luqman, A.; Nguyen, M.T.; Madlung, J.; Fan, S.H.; Macek, B.; Sass, P.; Bitschar, K.; Schittek, B.; Kretschmer, D.; et al. Staphylococcus aureus LPL protein triggers human host cell invasion via activation of hsp90 receptor. Cell Microbiol. 2020, 22 , e13111. [CrossRef]

103. Yang, Y.-H.; Jiang, Y.-L.; Zhang, J.; Wang, L.; Bai, X.-H.; Zhang, S.-J.; Ren, Y.-M.; Li, N.; Zhang, Y.-H.; Zhang, Z.; et al. Structural insights into SraP-mediated Staphylococcus aureus adhesion to host cells. PLoS Pathogens. 2014, 10, e1004169. [CrossRef]

104. Corrigan, R.M.; Miajlovic, H.; Foster, T.J. Surface proteins that promote adherence of Staphylococcus aureus to human desquamated nasal epithelial cells. BMC Microbiol. 2009, 9, 22. [CrossRef]

105. Askarian, F.; Uchiyama, S.; Valderrama, J.A.; Ajayi, C.; Sollid, J.U.; van Sorge, N.M.; Nizet, V.; van Strijp, J.A.; Johannessen, M. Serineaspartate repeat protein D increases Staphylococcus aureus virulence and survival in blood. Infect. Immun. 2017, 85, e00559-e00616. [CrossRef]

106. Claro, T.; Widaa, A.; O'Seaghdha, M.; Miajlovic, H.; Foster, T.J.; O'Brien, F.J.; Kerrigan, S.W. Staphylococcus aureus protein a binds to osteoblasts and triggers signals that weaken bone in osteomyelitis. PLoS ONE 2011, 6, e18748. [CrossRef] [PubMed]

107. Edwards, A.M.; Bowden, M.G.; Brown, E.L.; Laabei, M.; Massey, R.C. Staphylococcus aureus extracellular adherence protein triggers TNFA release, promoting attachment to endothelial cells via protein A. PLoS ONE 2012, 7, e43046. [CrossRef] [PubMed]

108. Viela, F.; Prystopiuk, V.; Leprince, A.; Mahillon, J.; Speziale, P.; Pietrocola, G.; Dufrêne, Y.F. Binding of staphylococcus aureus protein A to von willebrand factor is regulated by Mechanical Force. mBio 2019, 10, e00555-19. [CrossRef] [PubMed]

109. Soong, G.; Martin, F.J.; Chun, J.; Cohen, T.S.; Ahn, D.S.; Prince, A. Staphylococcus aureus protein a mediates invasion across airway epithelial cells through activation of rhoa GTPase signaling and proteolytic activity. J. Biol. Chem. 2011, 286, 35891-35898. [CrossRef] [PubMed]

110. Ji, Z.; Su, J.; Hou, Y.; Yao, Z.; Yu, B.; Zhang, X. EGFR/Fak and c-src signalling pathways mediate the internalisation of staphylococcus aureus by osteoblasts. Cell Microbiol. 2020, 22, e13240. [CrossRef]

111. Abel, J.; Goldmann, O.; Ziegler, C.; Höltje, C.; Smeltzer, M.S.; Cheung, A.L.; Bruhn, D.; Rohde, M.; Medina, E. Staphylococcus aureus evades the extracellular antimicrobial activity of mast cells by promoting its own uptake. J. Innate Immun. 2011, 3, 495-507. [CrossRef]

112. Goldmann, O.; Tuchscherr, L.; Rohde, M.; Medina, E. A-hemolysin enhances staphylococcus aureus internalization and survival within mast cells by modulating the expression of $\beta 1$ integrin. Cell Microbiol. 2016, 18, 807-819. [CrossRef]

113. Hermann, I.; Räth, S.; Ziesemer, S.; Volksdorf, T.; Dress, R.J.; Gutjahr, M.; Müller, C.; Beule, A.G.; Hildebrandt, J.-P. Staphylococcus aureus hemolysin a disrupts cell-matrix adhesions in human airway epithelial cells. Am. J. Respir. Cell Mol. Biol. 2015, 52, 14-24. [CrossRef]

114. Eiffler, I.; Behnke, J.; Ziesemer, S.; Müller, C.; Hildebrandt, J.-P. Staphylococcus aureus $\alpha$-toxin-mediated cation entry depolarizes membrane potential and activates p38 MAP kinase in airway epithelial cells. Am. J. Physiol. Lung Cell Mol. Physiol. 2016, 311, L676-L685. [CrossRef]

115. Wang, J.-H.; Zhang, K.; Wang, N.; Qiu, X.-M.; Wang, Y.-B.; He, P. Involvement of phosphatidylinositol 3-kinase/Akt signaling pathway in $\beta 1$ integrin-mediated internalization of Staphylococcus aureus by alveolar epithelial cells. J. Microbiol. 2013, 51, 644-650. [CrossRef]

116. Josse, J.; Laurent, F.; Diot, A. Staphylococcal adhesion and host cell invasion: Fibronectin-binding and other mechanisms. Front. Microbiol. 2017, 8, 2433. [CrossRef] [PubMed]

117. Bosi, E.; Monk, J.M.; Aziz, R.K.; Fondi, M.; Nizet, V.; Palsson, B.Ø. Comparative genome-scale modelling of staphylococcus aureus strains identifies strain-specific metabolic capabilities linked to pathogenicity. Proc. Natl. Acad. Sci. USA 2016, 113, E3801-E3809. [CrossRef] [PubMed]

118. Lebughe, M.; Phaku, P.; Niemann, S.; Mumba, D.; Peters, G.; Muyembe-Tamfum, J.-J.; Mellmann, A.; Strauß, L.; Schaumburg, F. The impact of the Staphylococcus aureus Virulome on infection in a developing country: A cohort study. Front. Microbiol. 2017, 8, 1662. [CrossRef] [PubMed]

119. Karki, A.B.; Neyaz, L.; Fakhr, M.K. Comparative genomics of plasmid-bearing staphylococcus aureus strains isolated from various retail meats. Front. Microbiol. 2020, 11, 574923. [CrossRef] [PubMed]

120. Naushad, S.; Nobrega, D.B.; Naqvi, S.A.; Barkema, H.W.; De Buck, J. Genomic analysis of bovine Staphylococcus aureus isolates from milk to elucidate diversity and determine the distributions of antimicrobial and virulence genes and their association with mastitis. mSystems 2020, 5, e00063-20. [CrossRef] [PubMed]

121. Fuchs, S.; Mehlan, H.; Bernhardt, J.; Hennig, A.; Michalik, S.; Surmann, K.; Pané-Farré, J.; Giese, A.; Weiss, S.; Backert, L.; et al. AureoWiki-The repository of the Staphylococcus aureus research and annotation community. Int. J. Med. Microbiol. 2018, 6, 558-568. [CrossRef] 
122. Albrecht, T.; Raue, S.; Rosenstein, R.; Nieselt, K.; Gotz, F. Phylogeny of the staphylococcal major Autolysin and its use in genus and species typing. J. Bacteriol. 2012, 194, 2630-2636. [CrossRef]

123. Manara, S.; Pasolli, E.; Dolce, D.; Ravenni, N.; Campana, S.; Armanini, F.; Asnicar, F.; Mengoni, A.; Galli, L.; Montagnani, C.; et al. Whole-genome epidemiology, characterisation, and phylogenetic reconstruction of Staphylococcus aureus strains in a paediatric hospital. Genome Med. 2018, 10, 82. [CrossRef]

124. Hussain, M.; von Eiff, C.; Sinha, B.; Joost, I.; Herrmann, M.; Peters, G.; Becker, K. eap Gene as novel target for specific identification of Staphylococcus aureus. J. Clin. Microbiol. 2008, 46, 470-476. [CrossRef]

125. Amissah, N.A.; Chlebowicz, M.A.; Ablordey, A.; Tetteh, C.S.; Prah, I.; van der werf, T.S.; Friedrich, A.W.; van Dijl, J.M.; Stienstra, Y.; Rossen, J.W. Virulence potential of Staphylococcus aureus isolates from Buruli ulcer patients. Int. J. Med. Microbiol. 2017, 307, $223-232$. [CrossRef]

126. Rollin, G.; Tan, X.; Tros, F.; Dupuis, M.; Nassif, X.; Charbit, A.; Coureuil, M. Intracellular Survival of Staphylococcus aureus in Endothelial Cells: A Matter of Growth or Persistence. Front. Microbiol. 2017, 8, 1354. [CrossRef] [PubMed]

127. Tuchscherr, L.; Medina, E.; Hussain, M.; Völker, W.; Heitmann, V.; Niemann, S.; Holzinger, D.; Roth, J.; Proctor, R.A.; Becker, K.; et al. Staphylococcus aureus phenotype switching: An effective bacterial strategy to escape host immune response and establish a chronic infection. EMBO Mol. Med. 2011, 3, 129-141. [CrossRef] [PubMed]

128. Flannagan, R.S.; Heit, B.; Heinrichs, D.E. Intracellular replication of Staphylococcus aureus in mature phagolysosomes in macrophages precedes host cell death, and bacterial escape and dissemination. Cell Microbiol. 2016, 18, 514-535. [CrossRef] [PubMed]

129. Grosz, M.; Kolter, J.; Paprotka, K.; Winkler, A.-C.; Schäfer, D.; Chatterjee, S.S.; Geiger, T.; Wolz, C.; Ohlsen, K.; Otto, M.; et al. Cytoplasmic Replication of Staphylococcus aureus upon phagosomal escape triggered by phenol-soluble modulin $\alpha$. Cell Microbiol. 2014, 16, 451-465. [CrossRef] [PubMed]

130. Lacoma, A.; Cano, V.; Moranta, D.; Regueiro, V.; Domínguez-Villanueva, D.; Laabei, M.; González-Nicolau, M.; Ausina, V.; Prat, C.; Bengoechea, J.A. Investigating intracellular persistence of Staphylococcus aureus within a murine alveolar macrophage cell line. Virulence 2017, 8, 1761-1775. [CrossRef]

131. Tranchemontagne, Z.R.; Camire, R.B.; O’Donnell, V.J.; Baugh, J.; Burkholder, K.M. Staphylococcus aureus strain USA300 perturbs acquisition of lysosomal enzymes and requires phagosomal acidification for survival inside macrophages. Infect. Immun. 2015, 84, 241-253. [CrossRef]

132. Flannagan, R.S.; Kuiack, R.C.; McGavin, M.J.; Heinrichs, D.E. Staphylococcus aureus uses the GRAXRS regulatory system to sense and adapt to the acidified phagolysosome in macrophages. Mbio 2018, 9, e01143-18. [CrossRef]

133. Zhou, C.; Bhinderwala, F.; Lehman, M.K.K.; Thomas, V.C.; Chaudhari, S.S.; Yamada, K.J.; Foster, K.W.; Powers, R.; Kielian, T.; Fey, P.D. Urease is an essential component of the acid response network of staphylococcus aureus and is required for a persistent murine kidney infection. PLoS Pathog. 2019, 15, e1007538. [CrossRef]

134. Jubrail, J.; Morris, P.; Bewley, M.A.; Stoneham, S.; Johnston, S.A.; Foster, S.J.; Peden, A.A.; Read, R.C.; Marriott, H.M.; Dockrell, D.H. Inability to sustain intraphagolysosomal killing of Staphylococcus aureus predisposes to bacterial persistence in macrophages. Cell Microbiol. 2016, 18, 80-96. [CrossRef]

135. Kubica, M.; Guzik, K.; Koziel, J.; Zarebski, M.; Richter, W.; Gajkowska, B.; Golda, A.; Maciag-Gudowska, A.; Brix, K.; Shaw, L.; et al. A potential new pathway for Staphylococcus aureus dissemination: The silent survival of $S$. aureus phagocytosed by human monocyte-derived macrophages. PLoS ONE 2008, 3, e1409. [CrossRef]

136. Flannagan, R.; Heit, B.; Heinrichs, D. Antimicrobial mechanisms of macrophages and the immune evasion strategies of Staphylococcus aureus. Pathogens 2015, 4, 826-868. [CrossRef] [PubMed]

137. Lehar, S.M.; Pillow, T.; Xu, M.; Staben, L.; Kajihara, K.K.; Vandlen, R.; DePalatis, L.; Raab, H.; Hazenbos, W.L.; Hiroshi Morisaki, J.; et al. Novel antibody-antibiotic conjugate eliminates intracellular S. aureus. Nature 2015, 527, 323-328. [CrossRef] [PubMed]

138. Surewaard, B.G.J.; Deniset, J.F.; Zemp, F.J.; Amrein, M.; Otto, M.; Conly, J.; Omri, A.; Yates, R.M.; Kubes, P. Identification and treatment of the Staphylococcus aureus reservoir in vivo. J. Exp. Med. 2016, 213, 1141-1151. [CrossRef] [PubMed]

139. Pollitt, E.J.; Szkuta, P.T.; Burns, N.; Foster, S.J. Staphylococcus aureus infection dynamics. PLoS Pathog. 2018, 14, e1007112. [CrossRef]

140. Giese, B.; Glowinski, F.; Paprotka, K.; Dittmann, S.; Steiner, T.; Sinha, B.; Fraunholz, M.J. Expression of $\delta$-toxin by Staphylococcus aureus mediates escape from phago-endosomes of human epithelial and endothelial cells in the presence of $\beta$-toxin. Cell Microbiol. 2011, 13, 316-329. [CrossRef]

141. Chi, C.-Y.; Lin, C.-C.; Liao, I.-C.; Yao, Y.-C.; Shen, F.-C.; Liu, C.-C.; Lin, C.-F. Panton-Valentine Leukocidin facilitates the escape of Staphylococcus aureus from human keratinocyte endosomes and induces apoptosis. J. Infect. Dis. 2014, 209, 224-235. [CrossRef]

142. Huitema, L.; Phillips, T.; Alexeev, V.; Tomic-Canic, M.; Pastar, I.; Igoucheva, O. Intracellular escape strategies of Staphylococcus aureus in persistent cutaneous infections. Exp. Dermatol. 2020, 30, 1428-1439. [CrossRef]

143. Blättner, S.; Das, S.; Paprotka, K.; Eilers, U.; Krischke, M.; Kretschmer, D.; Remmele, C.W.; Dittrich, M.; Müller, T.; SchueleinVoelk, C.; et al. Staphylococcus aureus exploits a non-ribosomal cyclic dipeptide to modulate survival within epithelial cells and phagocytes. PLoS Pathog. 2016, 12, e1005857. [CrossRef]

144. Wang, R.; Braughton, K.R.; Kretschmer, D.; Bach, T.-H.L.; Queck, S.Y.; Li, M.; Kennedy, A.D.; Dorward, D.W.; Klebanoff, S.J.; Peschel, A.; et al. Identification of novel cytolytic peptides as key virulence determinants for community-associated MRSA. Nat. Med. 2007, 13, 1510-1514. [CrossRef] 
145. Chatterjee, S.S.; Joo, H.-S.; Duong, A.C.; Dieringer, T.D.; Tan, V.Y.; Song, Y.; Fischer, E.R.; Cheung, G.Y.; Li, M.; Otto, M. Essential Staphylococcus aureus toxin export system. Nat. Med. 2013, 19, 364-367. [CrossRef]

146. Giese, B.; Dittmann, S.; Paprotka, K.; Levin, K.; Weltrowski, A.; Biehler, D.; Lâm, T.T.; Sinha, B.; Fraunholz, M.J. Staphylococcal alphatoxin is not sufficient to mediate escape from phagolysosomes in upper-airway epithelial cells. Infect. Immun. 2009, 77, 3611-3625. [CrossRef] [PubMed]

147. Münzenmayer, L.; Geiger, T.; Daiber, E.; Schulte, B.; Autenrieth, S.E.; Fraunholz, M.; Wolz, C. Influence of Sae-regulated and Agr-regulated factors on the escape of Staphylococcus aureus from human macrophages. Cell. Microbiol. 2016, 18, $1172-1183$. [CrossRef] [PubMed]

148. Truong-Bolduc, Q.C.; Khan, N.S.; Vyas, J.M.; Hooper, D.C. Tet38 efflux pump affects Staphylococcus aureus internalization by epithelial cells through interaction with CD36 and contributes to bacterial escape from acidic and nonacidic phagolysosomes. Infec. Immun. 2017, 85, e00862-16. [CrossRef] [PubMed]

149. Deretic, V.; Saitoh, T.; Akira, S. Autophagy in infection, inflammation and immunity. Nat. Rev. Immunol. 2013, 13, $722-737$. [CrossRef] [PubMed]

150. Galluzzi, L.; Pietrocola, F.; Levine, B.; Kroemer, G. Metabolic control of Autophagy. Cell 2014, 159, 1263-1276. [CrossRef] [PubMed]

151. Mostowy, S. Autophagy and bacterial clearance: A not so clear picture. Cell. Microbiol. 2012, 15, 395-402. [CrossRef]

152. Fang, L.; Wu, H.-M.; Ding, P.-S.; Liu, R.-Y. TLR2 mediates phagocytosis and autophagy through JNK signaling pathway in Staphylococcus aureus-stimulated raw264.7 cells. Cell. Signal. 2014, 26, 806-814. [CrossRef]

153. Neumann, Y.; Bruns, S.A.; Rohde, M.; Prajsnar, T.K.; Foster, S.J.; Schmitz, I. Intracellular Staphylococcus aureus eludes selective autophagy by activating a host cell kinase. Autophagy 2016, 12, 2069-2084. [CrossRef]

154. O'Keeffe, K.M.; Wilk, M.M.; Leech, J.M.; Murphy, A.G.; Laabei, M.; Monk, I.R.; Massey, R.C.; Lindsay, J.A.; Foster, T.J.; Geoghegan, J.A.; et al. Manipulation of autophagy in phagocytes facilitates Staphylococcus aureus bloodstream infection. Infect. Immun. 2015 83, 3445-3457. [CrossRef]

155. Herb, M.; Gluschko, A.; Schramm, M. LC3-associated phagocytosis-the highway to hell for phagocytosed microbes. Semin. Cell Dev. Biol. 2020, 101, 68-76. [CrossRef]

156. Prajsnar, T.K.; Serba, J.J.; Dekker, B.M.; Gibson, J.F.; Masud, S.; Fleming, A.; Johnston, S.A.; Renshaw, S.A.; Meijer, A.H. The autophagic response to Staphylococcus aureus provides an intracellular niche in neutrophils. Autophagy 2020, 17, 888-902. [CrossRef] [PubMed]

157. Mestre, M.B.; Fader, C.M.; Sola, C.; Colombo, M.I. A-hemolysin is required for the activation of the autophagic pathway in Staphylococcus aureus infected cells. Autophagy 2010, 6, 110-125. [CrossRef] [PubMed]

158. Schnaith, A.; Kashkar, H.; Leggio, S.A.; Addicks, K.; Krönke, M.; Krut, O. Staphylococcus aureus subvert autophagy for induction of caspase-independent host cell death. J. Biol. Chem. 2007, 282, 2695-2706. [CrossRef] [PubMed]

159. Ma, J.; Gulbins, E.; Edwards, M.J.; Caldwell, C.C.; Fraunholz, M.; Becker, K.A. Staphylococcus aureus alpha-toxin induces inflammatory cytokines via lysosomal acid sphingomyelinase and ceramides. Cell. Physiol. Biochem. 2017, 43, 2170-2184. [CrossRef] [PubMed]

160. Becker, K.A.; Fahsel, B.; Kemper, H.; Mayeres, J.; Li, C.; Wilker, B.; Keitsch, S.; Soddemann, M.; Sehl, C.; Kohnen, M.; et al. Staphylococcus aureus alpha-toxin disrupts endothelial-cell tight junctions via acid sphingomyelinase and ceramide. Infect. Immun. 2018, 86, e00606-e00617. [CrossRef]

161. Bronesky, D.; Wu, Z.; Marzi, S.; Walter, P.; Geissmann, T.; Moreau, K.; Vandenesch, F.; Caldelari, I.; Romby, P. Staphylococcus aureus RNAIII and its regulon link quorum sensing, stress responses, metabolic adaptation, and regulation of virulence gene expression. Annu. Rev. Microbiol. 2016, 70, 299-316. [CrossRef]

162. Soong, G.; Paulino, F.; Wachtel, S.; Parker, D.; Wickersham, M.; Zhang, D.; Brown, A.; Lauren, C.; Dowd, M.; West, E.; et al. Methicillin-resistant Staphylococcus aureus adaptation to human keratinocytes. Mbio 2015, 6, e00289-15. [CrossRef]

163. Mulcahy, M.E.; O’Brien, E.C.; O'Keeffe, K.M.; Vozza, E.G.; Leddy, N.; McLoughlin, R.M. Manipulation of autophagy and apoptosis facilitates intracellular survival of Staphylococcus aureus in human neutrophils. Front. Immunol. 2020, 11, 565545. [CrossRef]

164. Bravo-Santano, N.; Ellis, J.K.; Mateos, L.M.; Calle, Y.; Keun, H.C.; Behrends, V.; Letek, M. Intracellular Staphylococcus aureus modulates host central carbon metabolism to activate autophagy. Msphere 2018, 3, e00374-18. [CrossRef]

165. López de Armentia, M.M.; Gauron, M.C.; Colombo, M.I. Staphylococcus aureus alpha-toxin induces the formation of dynamic tubules labeled with LC3 within host cells in a Rab7 and rab1b-dependent manner. Front. Cell. Infect. Microbiol. $2017,7,431$. [CrossRef]

166. Ashida, H.; Suzuki, T.; Sasakawa, C. Shigella infection and host cell death: A double-edged sword for the host and pathogen survival. Curr. Opin. Microbiol. 2021, 59, 1-7. [CrossRef] [PubMed]

167. Jorgensen, I.; Rayamajhi, M.; Miao, E.A. Programmed cell death as a defence against infection. Nat. Rev. Immunol. 2017, 17, 151-164. [CrossRef] [PubMed]

168. Missiakas, D.; Winstel, V. Selective host cell death by Staphylococcus aureus: A strategy for bacterial persistence. Front. Immunol. 2021, 11, 621733. [CrossRef] [PubMed]

169. Watkins, K.E.; Unnikrishnan, M. Evasion of host defenses by intracellular Staphylococcus aureus. Adv. Appl. Microbiol. 2020, 112, 105-141. [CrossRef] [PubMed]

170. Korea, C.G.; Balsamo, G.; Pezzicoli, A.; Merakou, C.; Tavarini, S.; Bagnoli, F.; Serruto, D.; Unnikrishnan, M. Staphylococcal ESX proteins modulate apoptosis and release of intracellular Staphylococcus aureus during infection in epithelial cells. Infect. Immun. 2014, 82, 4144-4153. [CrossRef] 
171. Kitur, K.; Parker, D.; Nieto, P.; Ahn, D.S.; Cohen, T.S.; Chung, S.; Wachtel, S.; Bueno, S.; Prince, A. Toxin-induced necroptosis is a major mechanism of Staphylococcus aureus lung damage. PLoS Pathog. 2015, 11, e1004820. [CrossRef]

172. Kitur, K.; Wachtel, S.; Brown, A.; Wickersham, M.; Paulino, F.; Peñaloza, H.F.; Soong, G.; Bueno, S.; Parker, D.; Prince, A. Necroptosis promotes Staphylococcus aureus clearance by inhibiting excessive inflammatory signaling. Cell Rep. 2016, 16, 2219-2230. [CrossRef]

173. Otto, M. Staphylococcus aureus toxins. Curr. Opin. Microbiol. 2014, 17, 32-37. [CrossRef]

174. Al Kindi, A.; Alkahtani, A.M.; Nalubega, M.; El-Chami, C.; O’Neill, C.; Arkwright, P.D.; Pennock, J.L. Staphylococcus aureus internalized by skin keratinocytes evade antibiotic killing. Front. Microbiol. 2019, 10, 2242. [CrossRef]

175. Stelzner, K.; Winkler, A.-C.; Liang, C.; Boyny, A.; Ade, C.P.; Dandekar, T.; Fraunholz, M.J.; Rudel, T. Intracellular Staphylococcus aureus perturbs the host cell $\mathrm{Ca}^{2+}$ homeostasis to promote cell death. Mbio 2020, 11, e02250-20. [CrossRef]

176. DuMont, A.L.; Yoong, P.; Surewaard, B.G.; Benson, M.A.; Nijland, R.; van Strijp, J.A.; Torres, V.J. Staphylococcus aureus elaborates leukocidin ab to mediate escape from within human neutrophils. Infect. Immun. 2013, 81, 1830-1841. [CrossRef] [PubMed]

177. Melehani, J.H.; James, D.B.; DuMont, A.L.; Torres, V.J.; Duncan, J.A. Staphylococcus aureus Leukocidin A/B (LukAB) kills human monocytes via host NLRP3 and ASC when extracellular, but not intracellular. PLoS Pathog. 2015, 11, e1004970. [CrossRef] [PubMed]

178. Ventura, C.L.; Malachowa, N.; Hammer, C.H.; Nardone, G.A.; Robinson, M.A.; Kobayashi, S.D.; DeLeo, F.R. Identification of a novel Staphylococcus aureus two-component leukotoxin using cell surface proteomics. PLoS ONE 2010, 5, e11634. [CrossRef] [PubMed]

179. Kobayashi, S.D.; Braughton, K.R.; Palazzolo-Ballance, A.M.; Kennedy, A.D.; Sampaio, E.; Kristosturyan, E.; Whitney, A.R.; Sturdevant, D.E.; Dorward, D.W.; Holland, S.M.; et al. Rapid neutrophil destruction following phagocytosis of Staphylococcus aureus. J. Innate Immun. 2010, 2, 560-575. [CrossRef] [PubMed]

180. Koziel, J.; Maciag-Gudowska, A.; Mikolajczyk, T.; Bzowska, M.; Sturdevant, D.E.; Whitney, A.R.; Shaw, L.N.; DeLeo, F.R.; Potempa, J. Phagocytosis of Staphylococcus aureus by macrophages exerts cytoprotective effects manifested by the upregulation of antiapoptotic factors. PLoS ONE 2009, 4, e5210. [CrossRef] [PubMed]

181. Cruciani, M.; Etna, M.P.; Camilli, R.; Giacomini, E.; Percario, Z.A.; Severa, M.; Sandini, S.; Rizzo, F.; Brandi, V.; Balsamo, G.; et al. Staphylococcus aureus ESX factors control human dendritic cell functions conditioning th1/th17 response. Front. Cell. Infect. Microbiol. 2017, 7, 330. [CrossRef] [PubMed]

182. Kerr, K.G.; Snelling, A.M. Pseudomonas aeruginosa: A formidable and ever-present adversary. J. Hosp. Infect. 2009, 73, 338-344. [CrossRef] [PubMed]

183. Sause, W.E.; Buckley, P.T.; Strohl, W.R.; Lynch, A.S.; Torres, V.J. Antibody-based biologics and their promise to combat Staphylococcus aureus infections. Trends Pharm. Sci. 2016, 37, 231-241. [CrossRef]

184. Wang-Lin, S.X.; Balthasar, J.P. Pharmacokinetic and pharmacodynamic considerations for the use of monoclonal antibodies in the treatment of bacterial infections. Antibodies 2018, 7, 5. [CrossRef]

185. Yaeger, L.N.; Coles, V.E.; Chan, D.C.K.; Burrows, L.L. How to kill Pseudomonas-Emerging therapies for a challenging pathogen. Ann. N. Y. Acad. Sci. 2021, 1496, 59-81. [CrossRef]

186. DiGiandomenico, A.; Keller, A.E.; Gao, C.; Rainey, G.J.; Warrener, P.; Camara, M.M.; Bonnell, J.; Fleming, R.; Bezabeh, B.; Dimasi, N.; et al. A multifunctional bispecific antibody protects against Pseudomonas aeruginosa. Sci. Transl. Med. 2014, 6, 262 ra155. [CrossRef] [PubMed]

187. AstraZeneca. Clinical Trials Appendix Q1 2020 Results Update. Available online: https:/ /www.astrazeneca.com/content/dam/ az/PDF/2020/q1-2020/Q1_2020_results_clinical_trials_appendix.pdf (accessed on 28 September 2021).

188. Kajihara, K.K.; Pantua, H.; Hernandez-Barry, H.; Hazen, M.; Deshmukh, K.; Chiang, N.; Ohri, R.; Castellanos, E.R.; Martin, L.; Matsumoto, M.L.; et al. Potent killing of Pseudomonas aeruginosa by an antibody-antibiotic conjugate. mBio 2021, 12, e00202-21. [CrossRef] [PubMed]

189. Evans, M.D.; Sammelson, R.; McDowell, S. Differential effects of cotreatment of the antibiotic rifampin with host-directed therapeutics in reducing intracellular Staphylococcus aureus infection. PeerJ 2020, 8, e10330. [CrossRef] [PubMed]

190. Xiao, Y.; Zhang, T.-S.; Li, Y.-H.; Liu, C.-F.; Yang, S.-J.; Zeng, L.-T.; Huang, S.-H.; Deng, X.-Y.; Peng, L. Memantine promotes bactericidal effect of neutrophils against Infection with Pseudomonas aeruginosa and its drug-resistant strain, by improving reactive oxygen species generation. Microb. Drug Resist. 2022, 28, 7-17. [CrossRef]

191. Bravo-Santano, N.; Stölting, H.; Cooper, F.; Bileckaja, N.; Majstorovic, A.; Ihle, N.; Mateos, L.M.; Calle, Y.; Behrends, V.; Letek, M. Host-directed kinase inhibitors act as novel therapies against intracellular Staphylococcus aureus. Sci. Rep. 2019, 9, 4876. [CrossRef]

192. Bravo-Santano, N.; Capilla-Lasheras, P.; Mateos, L.M.; Calle, Y.; Behrends, V.; Letek, M. Identification of novel targets for host-directed therapeutics against intracellular Staphylococcus aureus. Sci. Rep. 2019, 9, 15435. [CrossRef]

193. Alphonse, M.P.; Rubens, J.H.; Ortines, R.V.; Orlando, N.A.; Patel, A.M.; Dikeman, D.; Wang, Y.; Vuong, I.; Joyce, D.P.; Zhang, J.; et al. Pan-caspase inhibition as a potential host-directed immunotherapy against MRSA and other bacterial skin infections. Sci. Transl. Med. 2021, 13, eabe9887. [CrossRef]

194. Poerio, N.; De Santis, F.; Rossi, A.; Ranucci, S.; De Fino, I.; Henriquez, A.; D’Andrea, M.M.; Ciciriello, F.; Lucidi, V.; Nisini, R.; et al. Liposomes loaded with phosphatidylinositol 5-phosphate improve the antimicrobial response to Pseudomonas aeruginosa in impaired macrophages from cystic fibrosis patients and limit airway inflammatory response. Front. Immunol. 2020, 11, 532225. [CrossRef]

195. Roberts, S.C.; Zembower, T.R. Global increases in antibiotic consumption: A concerning trend for WHO targets. Lancet Infect. Dis. 2021, 21, 10-11. [CrossRef] 
196. Klein, E.Y.; Milkowska-Shibata, M.; Tseng, K.K.; Sharland, M.; Gandra, S.; Pulcini, C.; Laxminarayan, R. Assessment of WHO antibiotic consumption and access targets in 76 countries, 2000-2015: An analysis of pharmaceutical sales data. Lancet Infect. Dis. 2021, 21, 107-115. [CrossRef]

197. National Health Commission of the People's Republic of China. China Antimicrobial Resistance Surveillance System (in Chinese). Available online: http:/ /www.carss.cn/ (accessed on 20 October 2021).

198. Hu, F.; Guo, Y.; Zhu, D.; Wang, F.; Jiang, X.; Xu, Y. Antimicrobial resistance profile of clinical isolates in hospitals across China: Report from the CHINET surveillance program, 2017 (in Chinese). Chin. J. Infect. Chemother. 2018, 18, $241-251$.

199. Wang, J.; Zhou, M.; Huang, G.; Guo, Z.; Sauser, J.; Metsini, A.; Pittet, D.; Zingg, W. Antimicrobial resistance in southern China: Results of prospective surveillance in Dongguan city, 2017. J. Hosp. Infect. 2020, 105, 188-196. [CrossRef] [PubMed]

200. Wang, J. The challenges of antimicrobial resistance surveillance in China. Am. J. Infect. Control 2019, 47, 1403-1404. [CrossRef] [PubMed]

201. Taylor, M.W. Vaccines against viral infections. In Viruses and Man: A History of Interactions; Springer: Cham, Switzerland, 2014; pp. 355-377. [CrossRef]

202. Jackson, L.A.; Anderson, E.J.; Rouphael, N.G.; Roberts, P.C.; Makhene, M.; Coler, R.N.; McCullough, M.P.; Chappell, J.D.; Denison, M.R.; Stevens, L.J.; et al. An mRNA vaccine against SARS-CoV-2-Preliminary report. N. Eng. J. Med. 2020, 383, $1920-1931$. [CrossRef] [PubMed]

203. Polack, F.P.; Thomas, S.J.; Kitchin, N.; Absalon, J.; Gurtman, A.; Lockhart, S.; Perez, J.L.; Pérez Marc, G.; Moreira, E.D.; Zerbini, C.; et al. Safety and efficacy of the BNT162b2 mRNA Covid-19 vaccine. N. Eng. J. Med. 2020, 383, 2603-2615. [CrossRef]

204. Syed, K.A.; Saluja, T.; Cho, H.; Hsiao, A.; Shaikh, H.; Wartel, T.A.; Mogasale, V.; Lynch, J.; Kim, J.H.; Excler, J.L.; et al. Review on the recent advances on Typhoid vaccine development and challenges ahead. Clin. Infect. Dis. 2020, 71, S141-S150. [CrossRef]

205. Lopez, A.L.; Gonzales, M.L.; Aldaba, J.G.; Nair, G.B. Killed oral cholera vaccines: History, development and implementation challenges. Ther. Adv. Vaccine 2014, 2, 123-136. [CrossRef]

206. Cherry, J.D. The 112-year odyssey of pertussis and pertussis vaccines-mistakes made and implications for the future. J. Pediat. Infect. Dis Soc. 2019, 8, 334-341. [CrossRef]

207. Dolstad, H.A.; Franke, M.F.; Vissieres, K.; Jerome, J.G.; Ternier, R.; Ivers, L.C. Factors associated with diarrheal disease among children aged 1-5 years in a cholera epidemic in rural Haiti. PLoS Negl. Trop. Dis. 2021, 15, e0009726. [CrossRef]

208. Zwerling, A.; Behr, M.A.; Verma, A.; Brewer, T.F.; Menzies, D.; Pai, M. The BCG World Atlas: A database of global BCG vaccination policies and practices. PLoS Med. 2011, 8, e1001012. [CrossRef]

209. Germanier, R.; Fürer, E. Characteristics of the attenuated oral vaccine strain "S. typhi" Ty 21a. Dev. Biol Stand. 1983, 53, 3-7. [PubMed]

210. Xu, D.; Cisar, J.O.; Poly, F.; Yang, J.; Albanese, J.; Dharmasena, M.; Wai, T.; Guerry, P.; Kopecko, D.J. Genome sequence of Salmonella enterica serovar Typhi oral vaccine strain Ty21a. Gen. Announ. 2013, 1, e00650-13. [CrossRef] [PubMed]

211. Sun, W.; Singh, A.K. Plague vaccine: Recent progress and prospects. NPJ Vaccine 2019, 4, 11. [CrossRef] [PubMed]

212. Gupta, S.S.; Bharati, K.; Sur, D.; Khera, A.; Ganguly, N.K.; Nair, G.B. Why is the oral cholera vaccine not considered an option for prevention of cholera in India? Analysis of possible reasons. Ind. J. Med. Res. 2016, 143, 545-551. [CrossRef]

213. Lundgren, A.; Bourgeois, L.; Carlin, N.; Clements, J.; Gustafsson, B.; Hartford, M.; Holmgren, J.; Petzold, M.; Walker, R.; Svennerholm, A.M. Safety and immunogenicity of an improved oral inactivated multivalent enterotoxigenic Escherichia coli (ETEC) vaccine administered alone and together with dmLT adjuvant in a double-blind, randomized, placebo-controlled Phase I study. Vaccine 2014, 32, 7077-7084. [CrossRef]

214. Chakraborty, S.; Harro, C.; DeNearing, B.; Bream, J.; Bauers, N.; Dally, L.; Flores, J.; Van de Verg, L.; Sack, D.A.; Walker, R. Evaluation of the safety, tolerability, and immunogenicity of an oral, inactivated whole-cell Shigella flexneri 2a vaccine in healthy adult subjects. Clin. Vaccine Immunol. 2016, 23, 315-325. [CrossRef]

215. Plotkin, S.A.; Orenstein, W.A.; Offit, P.A. (Eds.) Vaccines, 6th ed.; Elsevier: Philadelphia, PA, USA, 2013.

216. Bonner, K.; Welch, E.; Elder, K.; Cohn, J. Impact of pneumococcal conjugate vaccine administration in pediatric older age groups in low and middle income countries: A systematic review. PLoS ONE 2015, 10, e0135270. [CrossRef]

217. Thumburu, K.K.; Singh, M.; Das, R.R.; Jaiswal, N.; Agarwal, A.; Kumar, A.; Kaur, H. Two or three primary dose regime for Haemophilus influenzae type b conjugate vaccine: Meta-analysis of randomized controlled trials. Ther. Adv. Vaccine 2015, 3, 31-40. [CrossRef]

218. Henriques-Normark, B.; Normark, S. Bacterial vaccines and antibiotic resistance. Ups J. Med. Sci. 2014, 119, 205-208. [CrossRef]

219. Priebe, G.P.; Goldberg, J.B. Vaccines for Pseudomonas aeruginosa: A long and winding road. Expert Rev. Vaccine 2014, 13, 507-519. [CrossRef]

220. López-Siles, M.; Corral-Lugo, A.; McConnell, M.J. Vaccines for multidrug resistant Gram negative bacteria: Lessons from the past for guiding future success. FEMS. Microbiol. Rev. 2021, 45, fuaa054. [CrossRef] [PubMed]

221. McIntosh, E. Development of vaccines against the sexually transmitted infections gonorrhoea, syphilis, Chlamydia, herpes simplex virus, human immunodeficiency virus and Zika virus. Ther. Adv. Vaccine Immunother. 2020, 8, 2515135520923887. [CrossRef] [PubMed]

222. Baker, S.; Thomson, N.; Weill, F.X.; Holt, K.E. Genomic insights into the emergence and spread of antimicrobial-resistant bacterial pathogens. Science 2018, 360, 733-738. [CrossRef] [PubMed]

223. Sharma, N.; Singh, V.; Shyma, K.P. Role of parasitic vaccines in integrated control of parasitic diseases in livestock. Vet. World 2015, 8, 590-598. [CrossRef] [PubMed] 
224. Oliveira, L.; Wang, R.; Specht, C.A.; Levitz, S.M. Vaccines for human fungal diseases: Close but still a long way to go. NPJ Vaccine 2021, 6, 33. [CrossRef] [PubMed]

225. Sacks, D.L. Vaccines against tropical parasitic diseases: A persisting answer to a persisting problem. Nat. Immunol. 2014, 15, 403-405. [CrossRef]

226. World Health Organization. Sixty-Eighth World Health Assembly (WHA68.7); Agenda Item 15.1, Global Action Plan on Antimicrobial Resistance; World Health Organization: Geneva, Switzerland, 2015.

227. Mulani, M.S.; Kamble, E.E.; Kumkar, S.N.; Tawre, M.S.; Pardesi, K.R. Emerging strategies to combat ESKAPE pathogens in the era of antimicrobial resistance: A review. Front. Microbiol. 2019, 10, 539. [CrossRef] 